\title{
بحث بـنـواز
}

\section{مدى هشروعية القضشاء على الغائب في الشريعة الإسلامية}

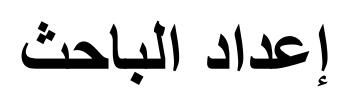

هشام بن محمد بن جمعان الغامدي

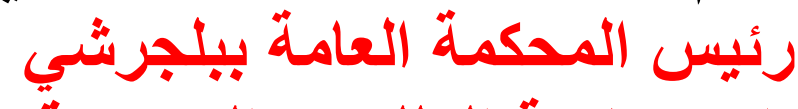

باحث دكتوراه - جامعة المثلك عبدالعزيز - قُّم الثريعة

$$
\text { و الار اسات الإسلامية. }
$$

\section{hesham-707@hotmail.com}

$$
\text { p r r = I I \& }
$$


مدي مشروعية القضاء على الغائب في الثريعة الإسلامية

- r9०. - 
مجلة كلية الثريعة والقانون بتفهنا الأثراف ـ دقهلية العدد الثالث والعثرون لسنة إr ـ بم الجزء الرابع

مدى مشروعية القضاء على الغائب في الشريعة الإسلامية

هشام بن محمد بن جمعان الغامدي .

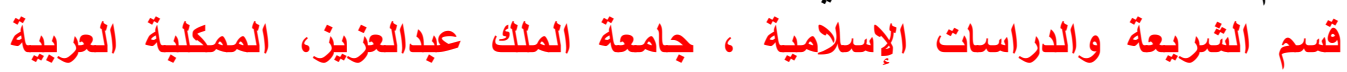

البريد الكتروني: hesham-707@hotmail.com

ملخص اللبحث:

يهدف هذا البحث للتعرف على مدى مشروعية القضاء على الغائب في الثريعة

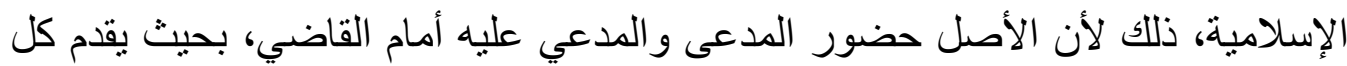
طرف من الأطر اف الأدلة والبر اهين التي تأكد صحة موقفه ودعو الاه واه والتي من خلالها يصدر القاضي حكمه في النزاع. إلا أن في كثير من الأحيان يكون المدعي عليه غائب عن بلد الحكم (المحكمة) أو ممتنع عن الحضور إلى القاضي، وعليه فقد اختلف الفقهاء حول إمكانية محاكمة إلهان الغائب في تللك الحالة على قولين.

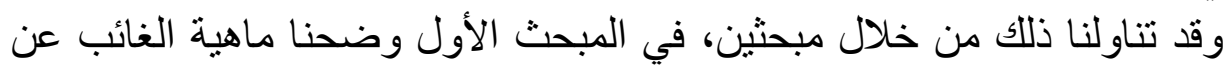

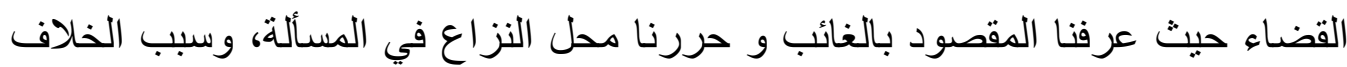

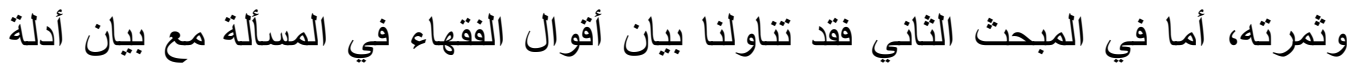

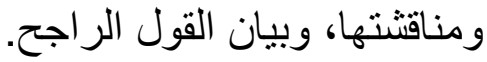
الكلمات الأثتاحية: مشروعية القضاء ، الغائب، الثريعة الإسلامية ، مجلس القضاء،

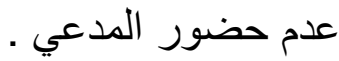


The extent of the legality of eliminating the absentee in Islamic law Hisham bin Mohammed bin Jamaan Al-Ghamdi

\section{Department of Sharia and Islamic Studies, King Abdulaziz}

\section{University, Kingdom of Saudi Arabia.}

Email: hesham-707@hotmail.com

\section{Abstract :}

This research aims to find out the extent of the legality of eliminating the absentee in Islamic law, because the principle is the presence of the defendant and the defendant before the judge, so that each of the parties provides evidence and evidence that confirms the correctness of his position and his case, through which the judge issues his judgment in the dispute.

However, in many cases, the defendant is absent from the country of judgment (the court) or abstains from attending the judge, and accordingly, the jurists differed about the possibility of trying the absentee in that case, based on two opinions.

We have dealt with this through two studies. In the first one we clarified what is absent from the judiciary, where we knew what is meant by the absent and we liberated the place of dispute in the issue, the reason for the disagreement and its fruit, and in the second topic we dealt with the statement of the sayings of the jurists in the matter with a statement of evidence and discussion, and a statement of the most correct opinion.

Key words: Legality Of The Judiciary, Absentee, Islamic Law, Judicial Council, non-attendance Of The Plaintiff. 
مجلة كلية الثريعة والقانون بتفهنا الأشراف ـ دقهلية العدد الثالث و العشرون لسنة إ ـ ب م الجزء الرابع

\section{مقدمة}

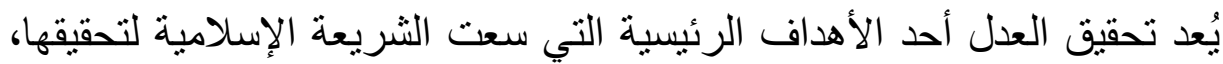

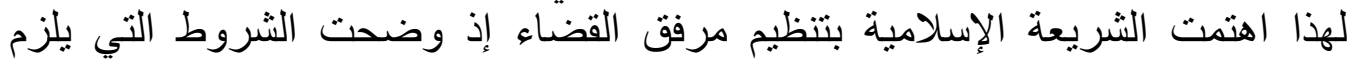

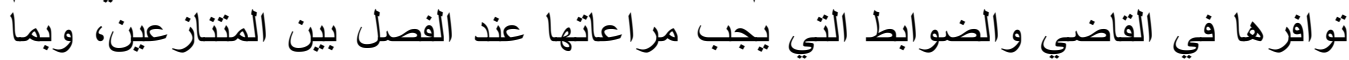

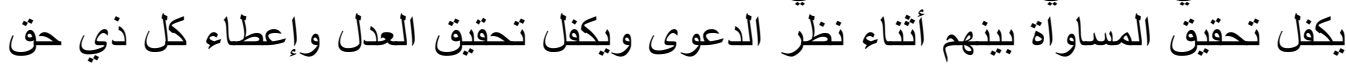

فمن عدالة الثريعة الإسلامية أنها لا تضيع حق من الحقوق، فتهتم بوجود الفاء

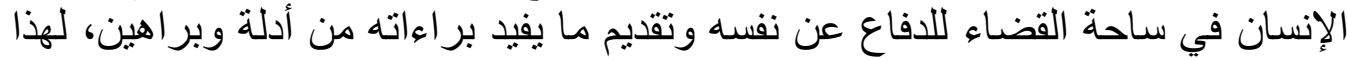

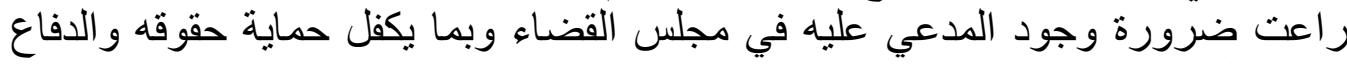
عنها بكل دليل ووسيلة مشروعة وجة المئ

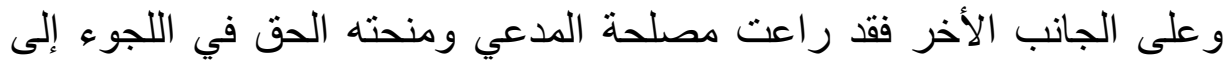
القضاء من أجل الوصول إلى حقه و إلا يكون عدم حضور المدي المدعي عليه أو المتهم سبيا

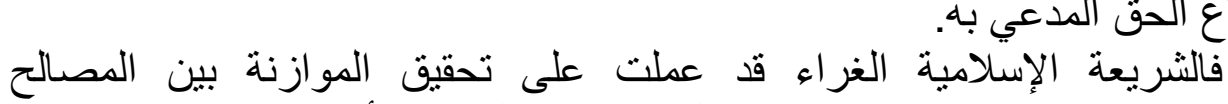

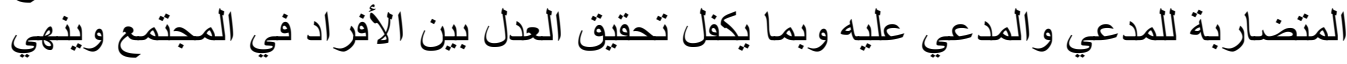

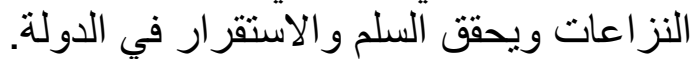

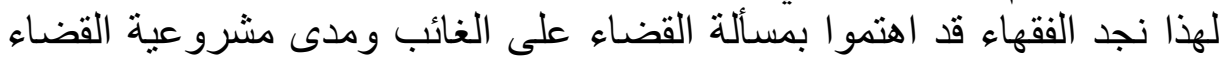
عليه وقد وقع بينهم خلاف كبير حول ذللك وهو ما نتتاوله من خلال هذا البحث.

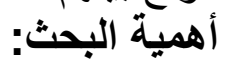

تظهر أهمية هذا البحث نظراً لأهمية مسألة القضاء على الغائب وما يترتب البهاء

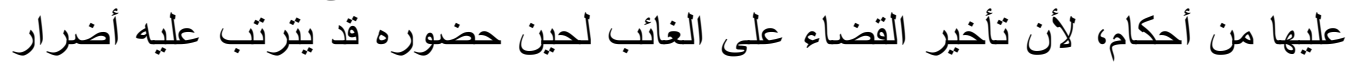

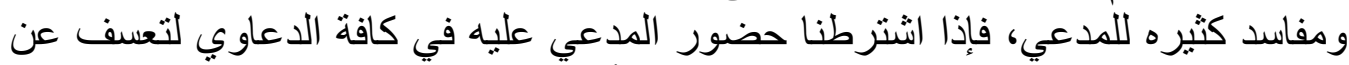
الحضور لمنع القضاء و الحكم عليه، وهنا تظهر أهية مشروعية الفية القضاء على على الغائب. أهداف البحث: البح: يهدف هذا البحث وبصفة أساسية للتعرف على المقصود بالغائب عن مجلس القضاء ومدى مشروعية القضاء و الحكم عليه إذ أمتنع عن الحضور أمام القاضي وآراء ألقاء

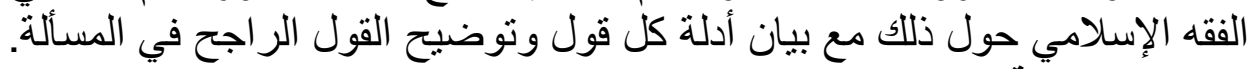

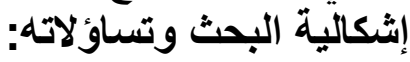

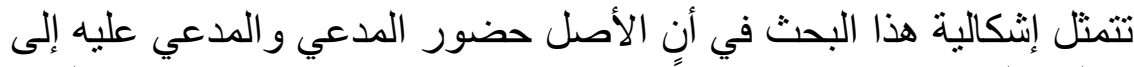

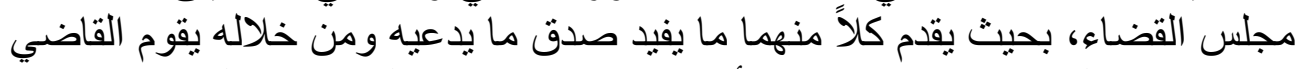
بالحكم و الفصل بينهم بعد تمحيص الأدلة و البر اهين وبما يكفل إعطاء كل ذي حقد حقد حقه. 
إلا أن المدعي عليه قد يغيب عن الحضور إلى مجلس القضاء مما يترتب عليه إليه

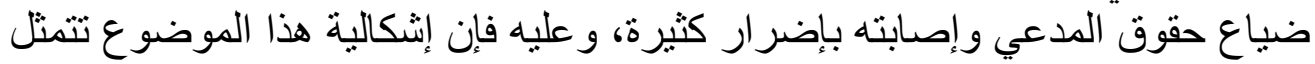

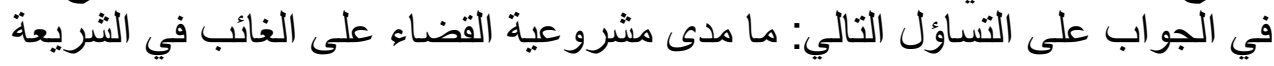

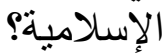
ويتفرع عن ذلك التساؤل العديد من الأسئلة الفرعية الأخرى و التي تتمثل فيما - من هو الغائب عن مجلس القضاء؟ لـاء؟

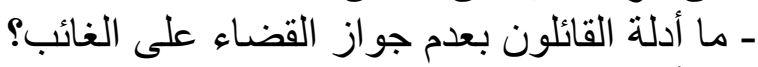
ـ ـ ما أدلة القائلون بمشرو عية القضاء على الفيلى الغائب؟ ـ - ما الر أي الر اجح في تلاك المسألة؟

يعتمد الباحث في تناول هذا البحث على الدنهج الوصفي التحليلي بحيث يتناول

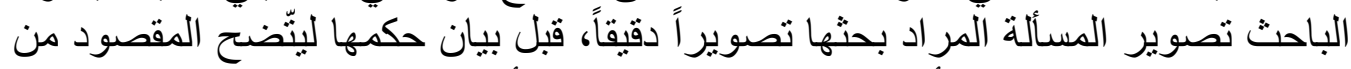

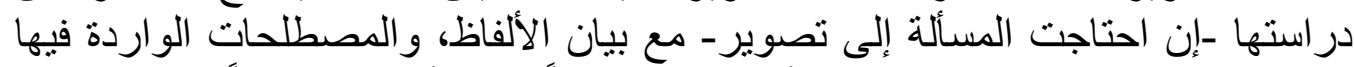

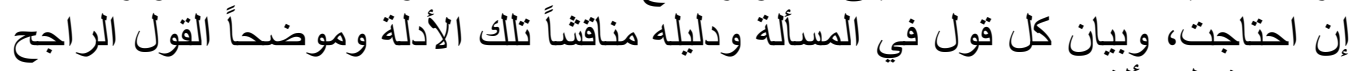

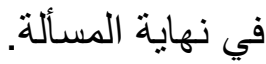

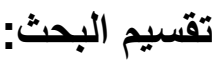

من أجل توضيح وبيان كافة الجوانب المتعلقة بالمسألة محل البحث، فقد تم تقسيم هذا البحث إلى مقدمة -تشمل بيان كانة أهمية البحث وأهدافه وإنشكاليته والمنهج العلمي-

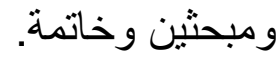


مجلة كلية الثريعة والقانون بتفهنا الأشراف ـ دقهلية العدد الثالث والعشرون لسنة اب ـ بم الجزء الرابع

\section{المبحث الأول}

\section{مافية الغائب عن القضئاي}

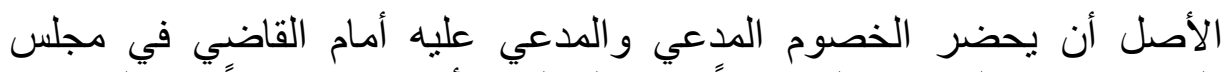

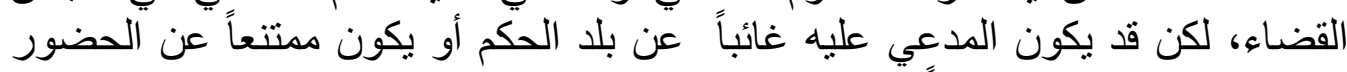

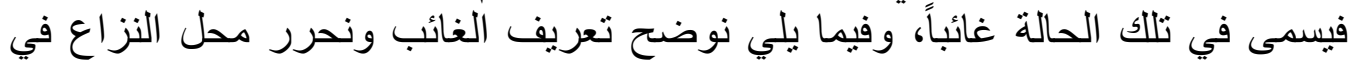

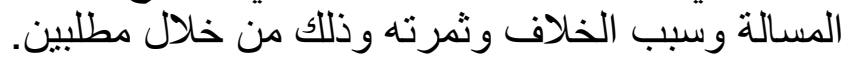

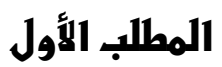

\section{تعربف الغائب ومحل النزاع في المسألة}

$$
\text { أولاً تعريف الغائب: }
$$

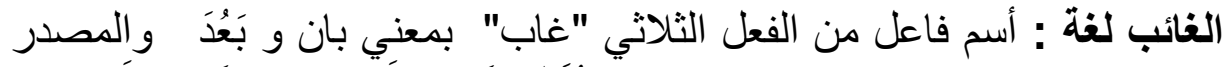

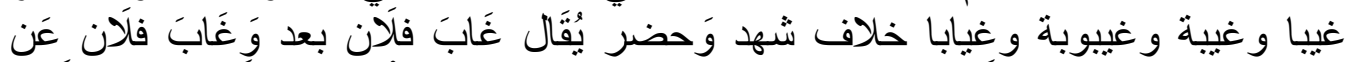

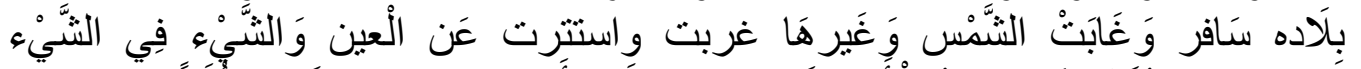

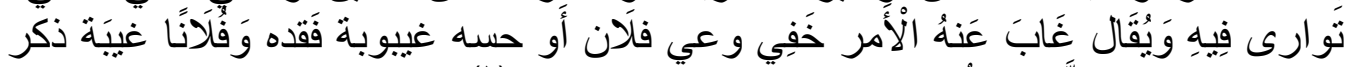

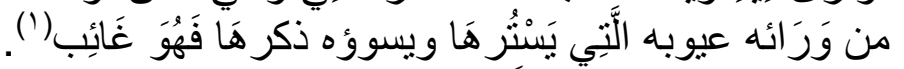

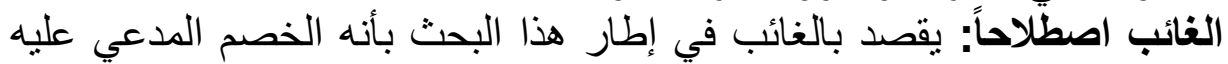

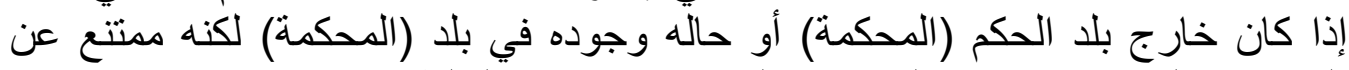

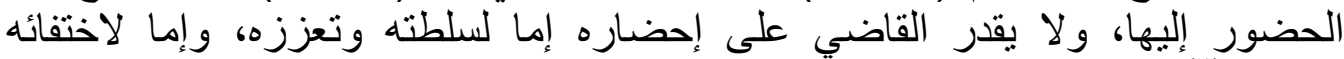

ثانياً تحرير محل النزاع في المسألة : لثانة وتستره (r)

لا يخلو أمر الغائب من ثلاث التان حالات

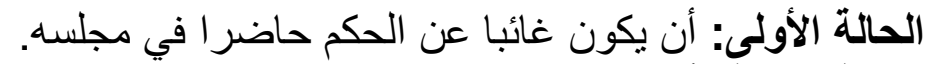

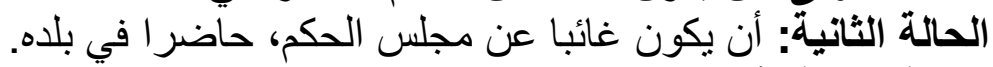

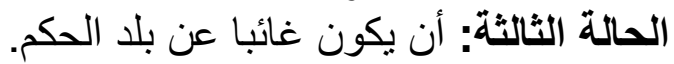

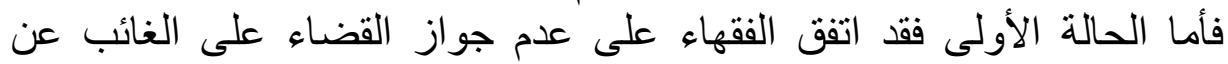

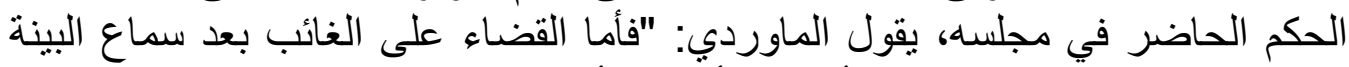

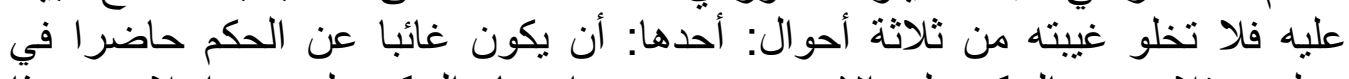

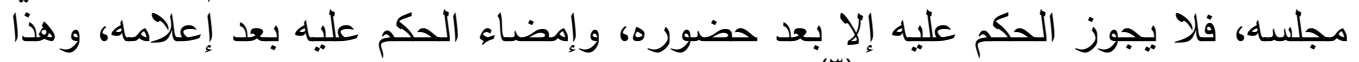
متفق عليه و إن اختلف في معناه"(r).

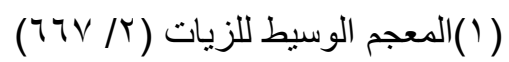

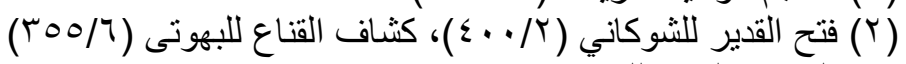

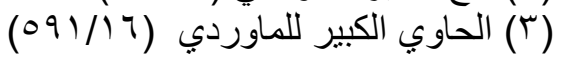




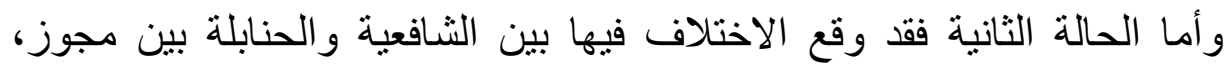

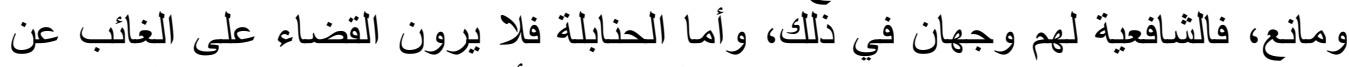

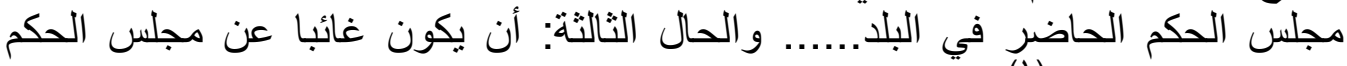

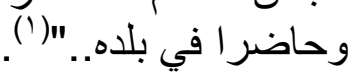

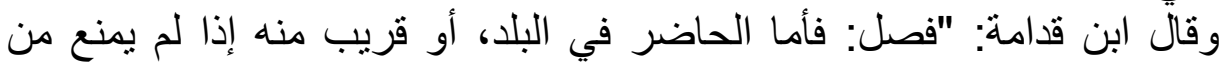

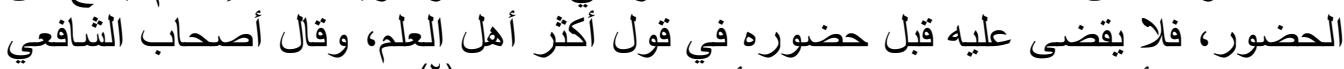

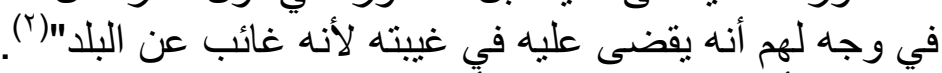

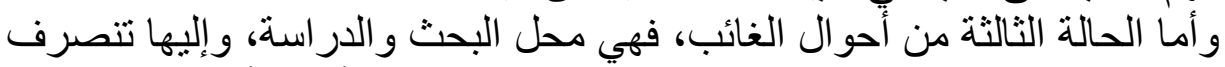

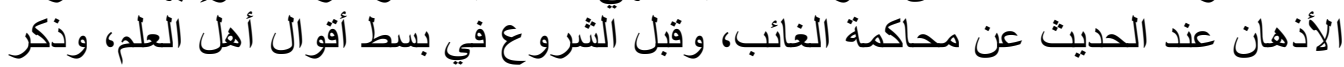

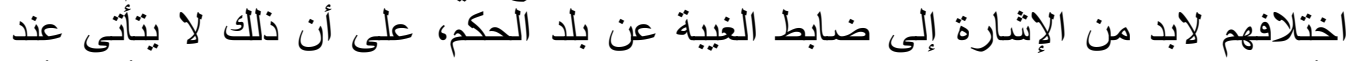

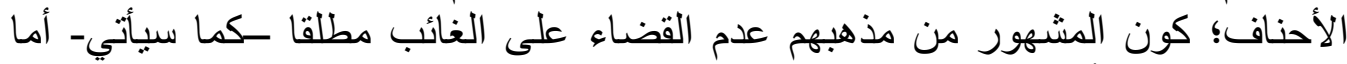

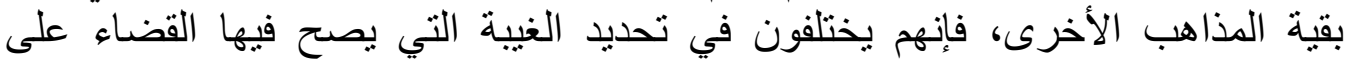

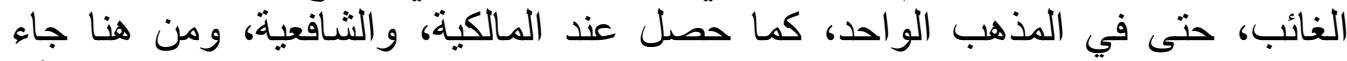

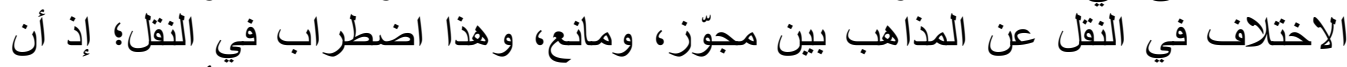

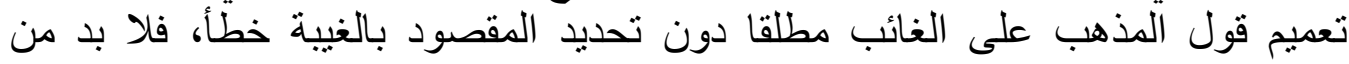

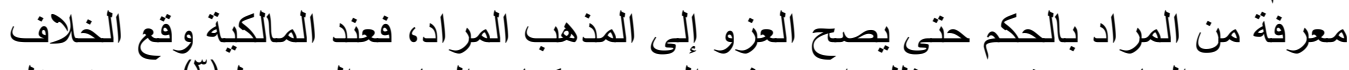

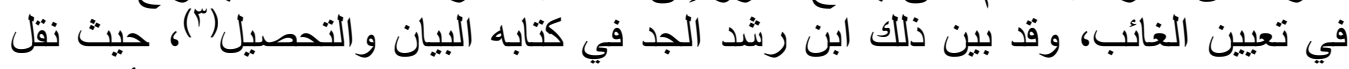

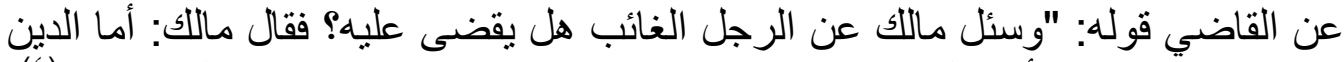

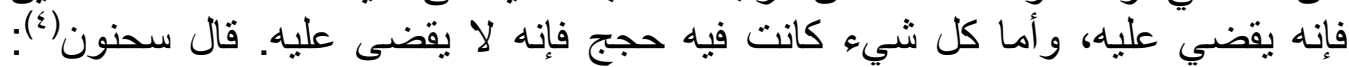

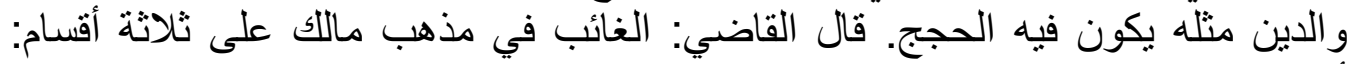

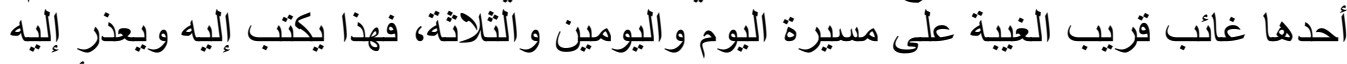

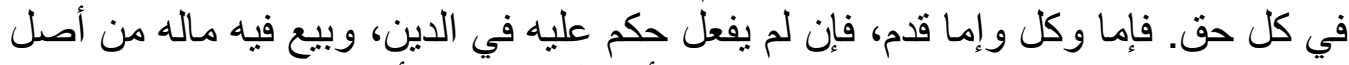

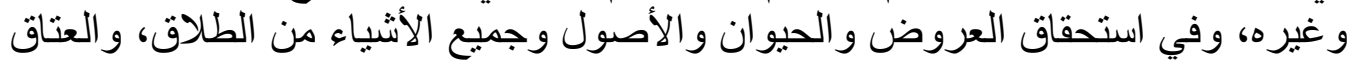

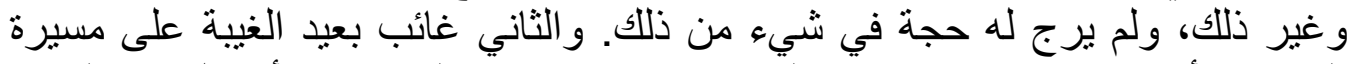

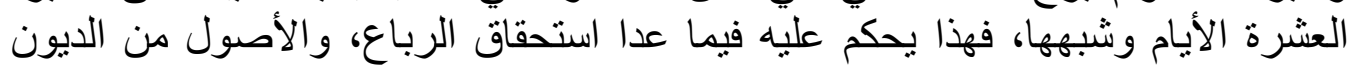

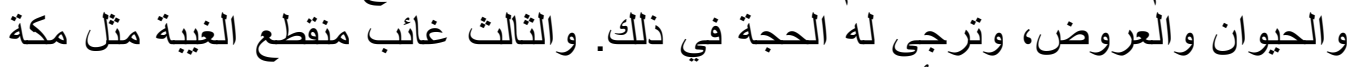

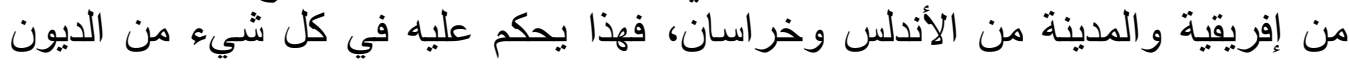

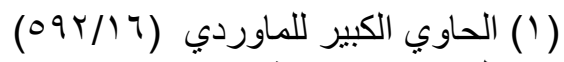

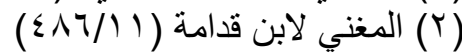

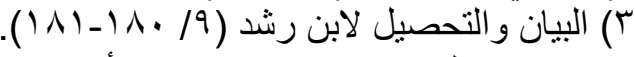

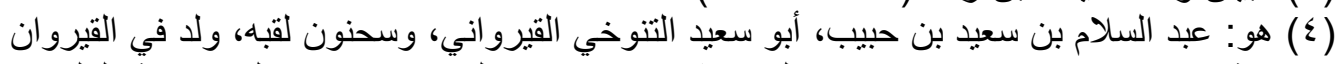

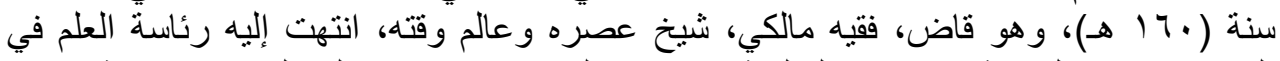

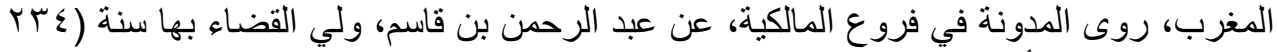

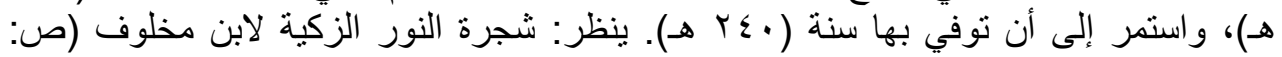

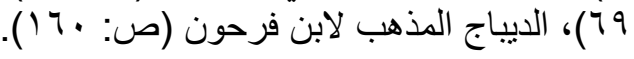


والعروض و الحيوان و الرباع والأصول، وترجى له الحجة في ذلك، فالغائب الذي تكلم

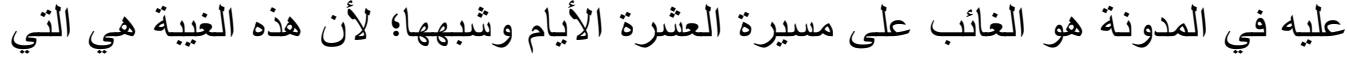

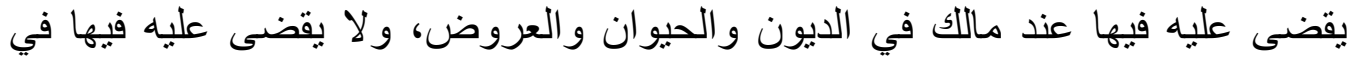

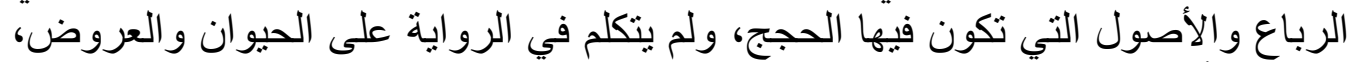

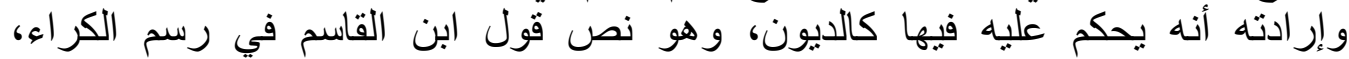

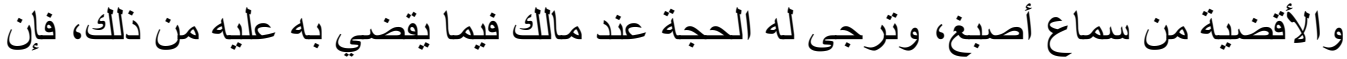

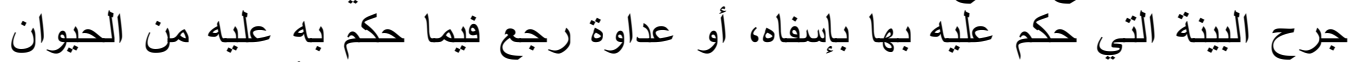

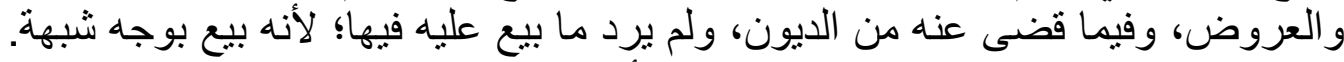

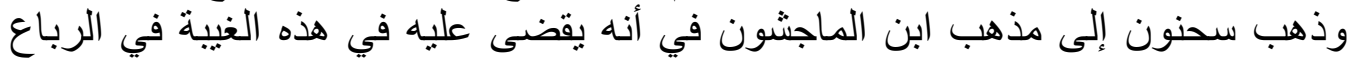

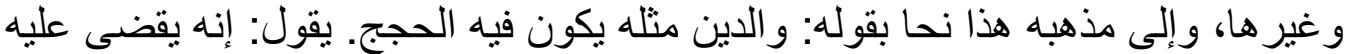

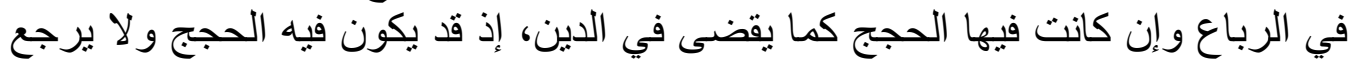

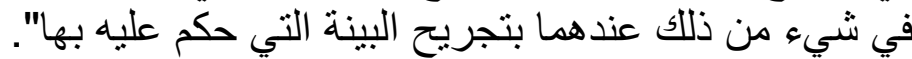

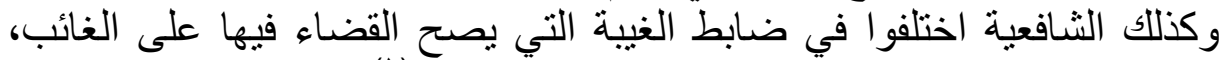

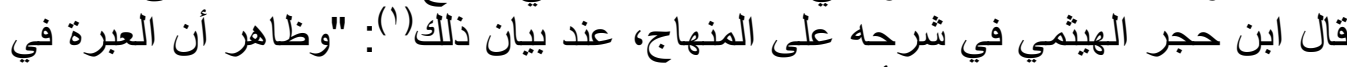

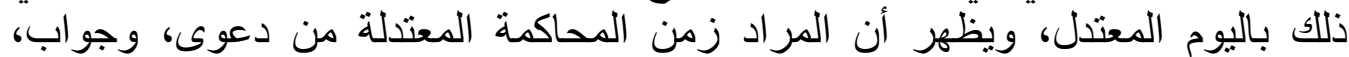

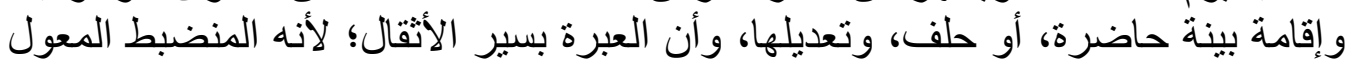

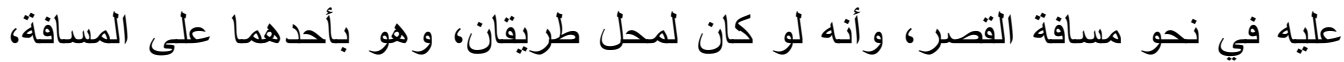

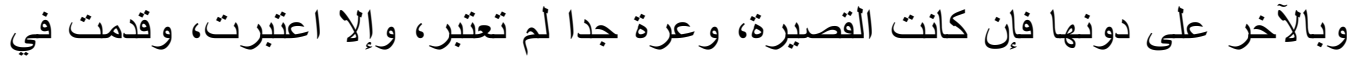

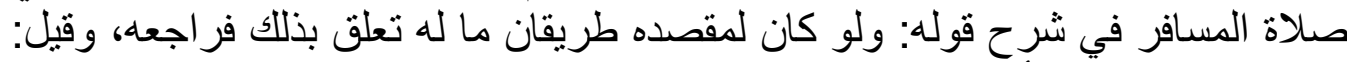

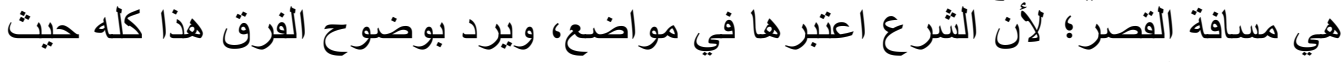

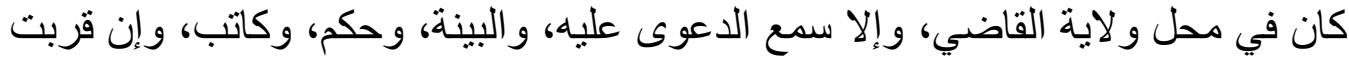
قاله الماوردي، وفيره ولائه

أما الحنابلة فالغيبة التي تجوز الحكم على الغائب عندهم منضبطة محددة بمسافة

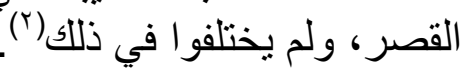

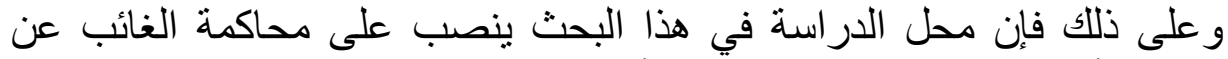

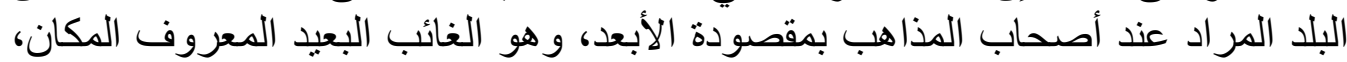

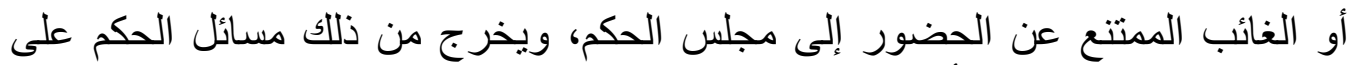

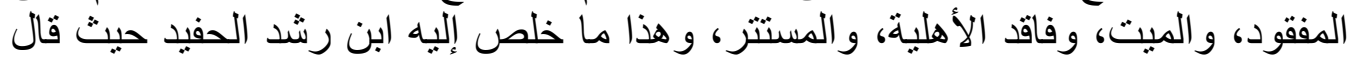

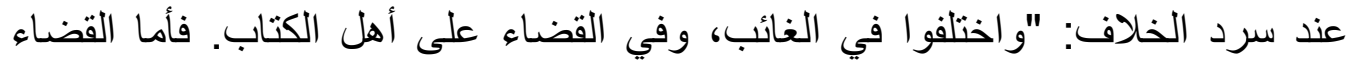


على الغائب، فإن مالكا، والثافعي قالا: يقضي على الغائب البعيد الغيبة، وقال أبو حنيفة:

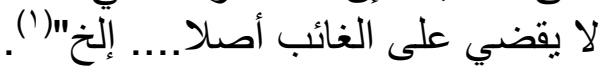

\section{المطlli}

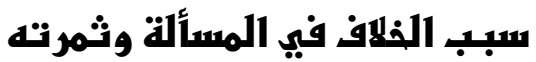

أولا: سبب الخلاف في مسألة القضاء على الغائب:

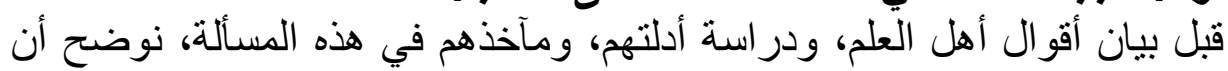

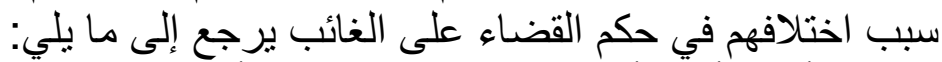

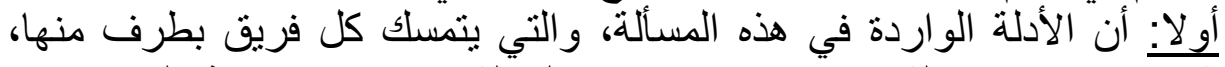

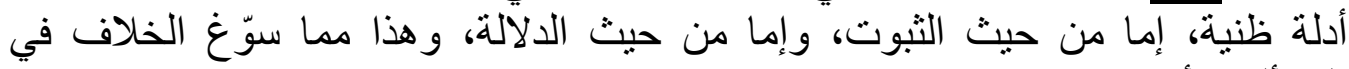

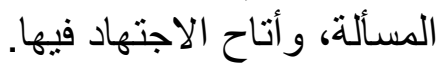

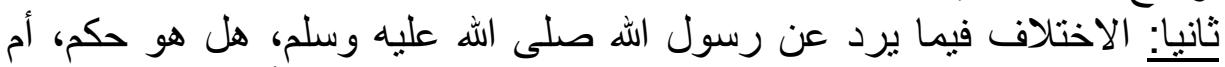

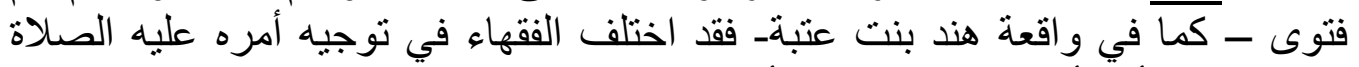

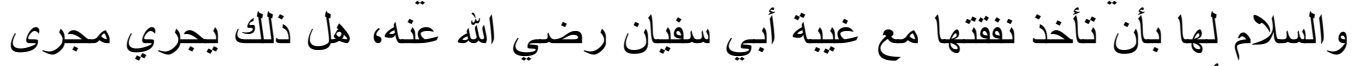
فمن رأى أن ذلك حكم صحح الحكم على الغائب، ومن قال بأنها فتوى، منع من الحكم على الغائب.

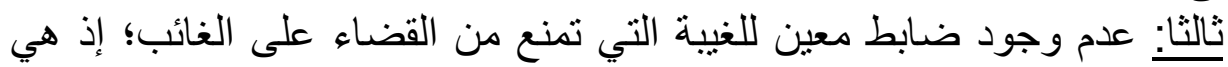

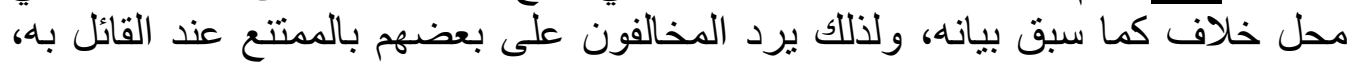

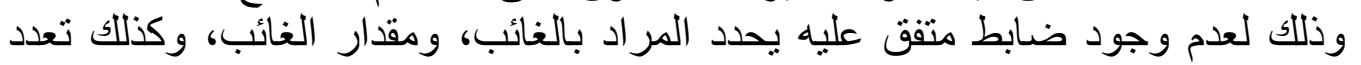
حالات الغياب، بعدا وقربا، ودئ، وحكما.

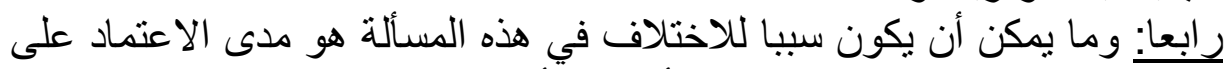

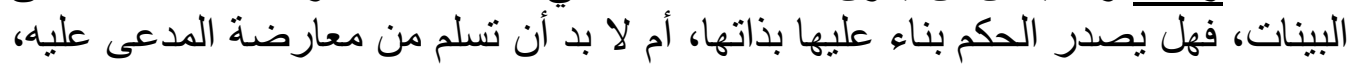

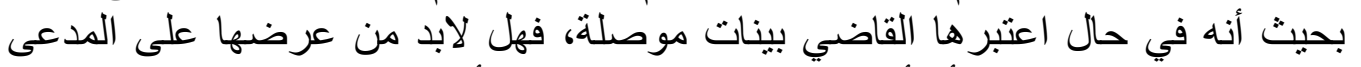

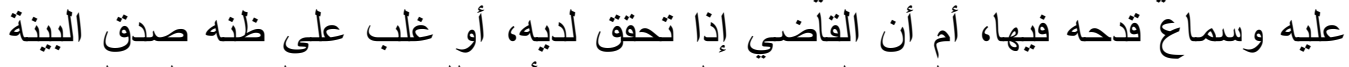

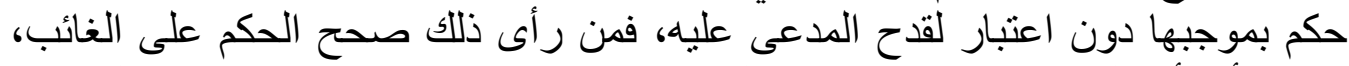

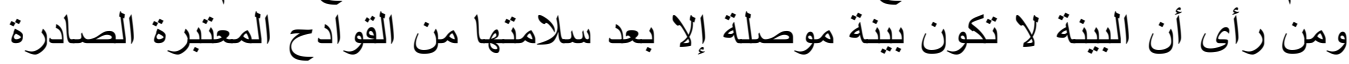
من المدعى عليه، منع من الحكم على لاينى الغائب. 
مجلة كلية الثريعة والقانون بتفهنا الأشر اف ـ دقهلية العدد الثالث و العشرون لسنة اب ـ ب ام الجزء الرابع

$$
\text { ثانيا: نوع الخلاف وثُمرته: }
$$

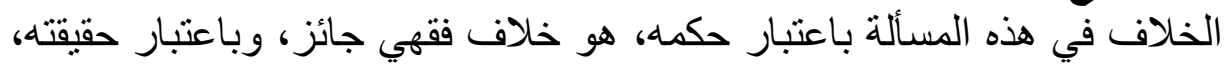

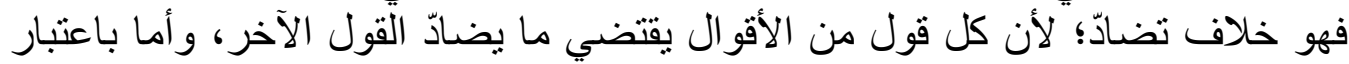

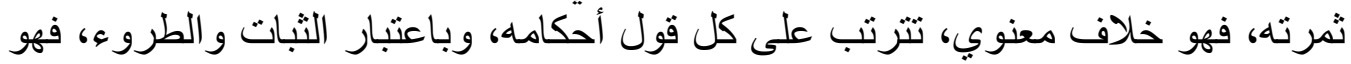
خلاف ثابت.

\section{ثمرة الخلاف:}

تظهر ثمرة الخلاف في هذه المسألة في صحة الحكم على الغائب إذا تحققت

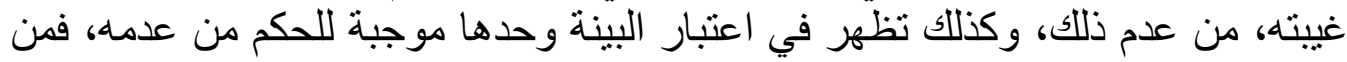

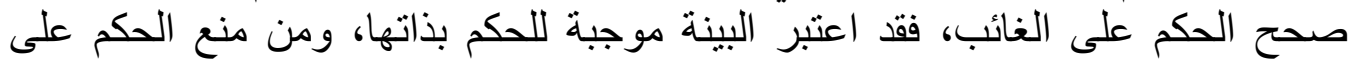

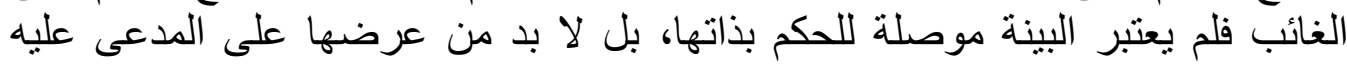
وسماع ما لديه حيالها. 


\section{الإبمث الثاني}

\section{أقوال الفقهاء في القضشاء على الغائب أبن}

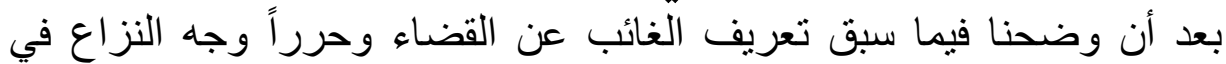

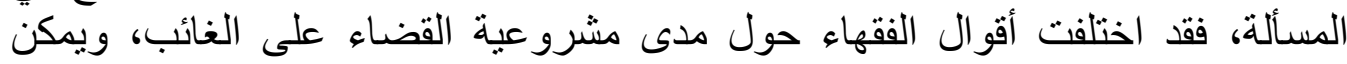

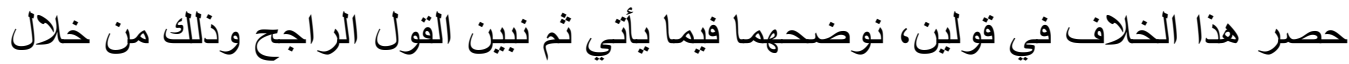

\section{المطلب الأول}

\section{القائلون بـهدم جواز القضضاء على الغائب}

ذهب بعض الفقهاء إلى القول بأنه لا يجوز القضاء إنهاء على الغائب مطلقا، وهذاء

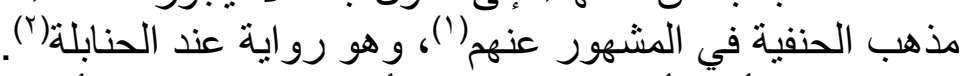

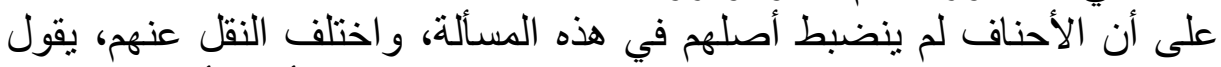

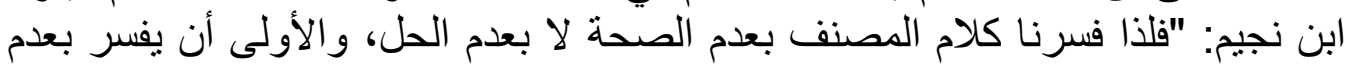

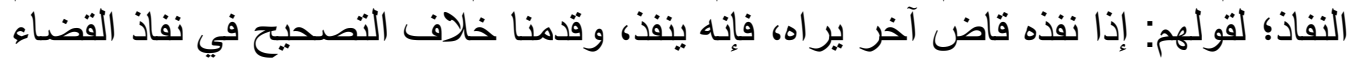

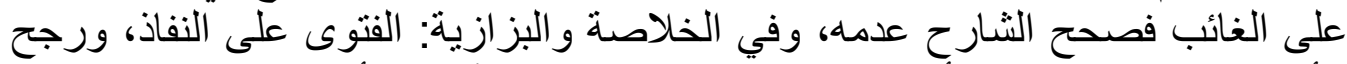

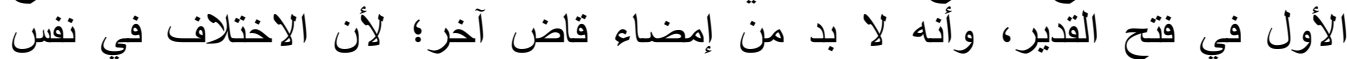

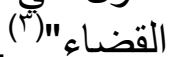

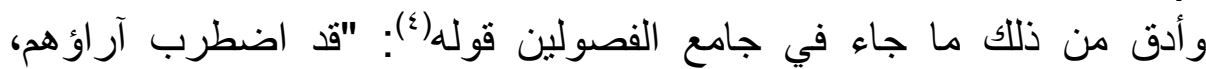

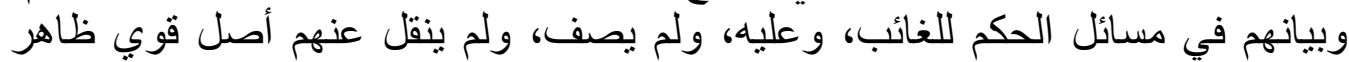

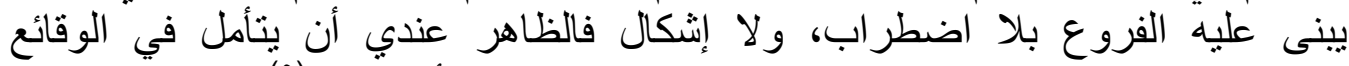

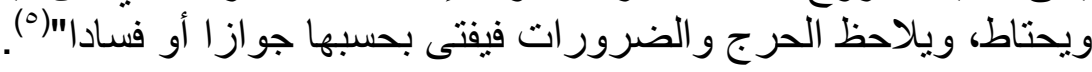

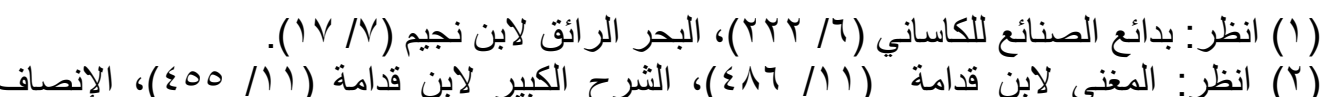

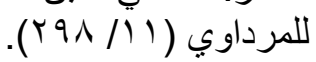

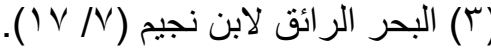

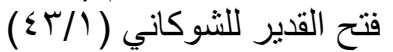

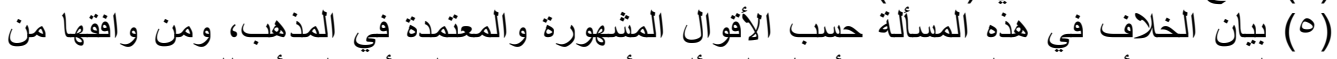

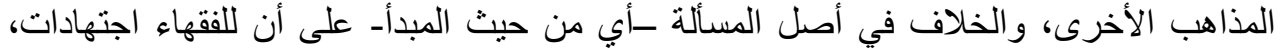

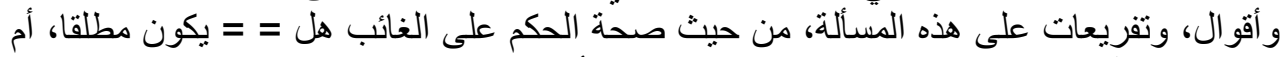

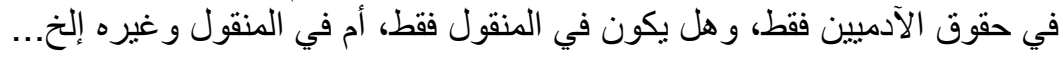


مجلة كلية الثريعة والقانون بتفهنا الأشراف ـ دقهلية العدد الثالث والعشرون لسنة اب ـ بم الجزء الرابع

وقدٍ استذل أصحاب هذا القول على عدم جواز القضاء على الغائب بما يأتي:

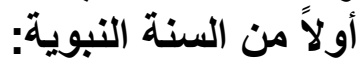
ا - ما رو اه علي بن أبي طالب رضي الله عنه قال: قال لي رسول الله صلى الله

عليه وسلم:

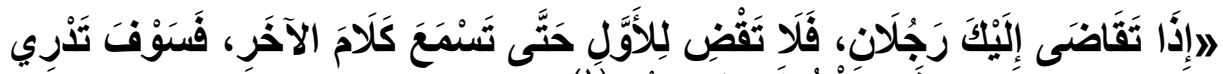

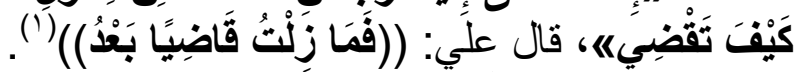

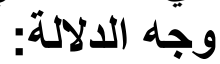

قال الكاساني: "نهاه - عليه الصلاة و السلام - عن القضاء لألاء الحد الخصمين قبل

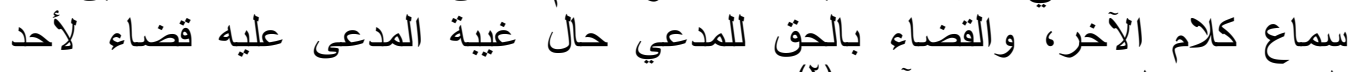
الخصمين، قبل سماع كلام الآخر "(').

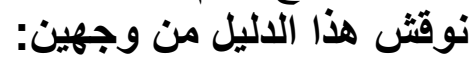

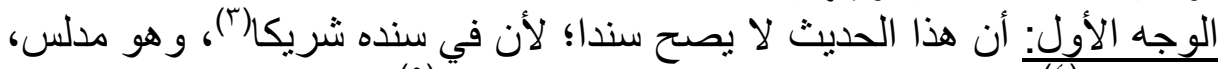

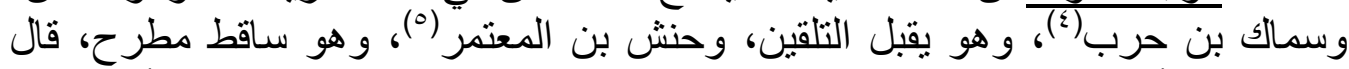

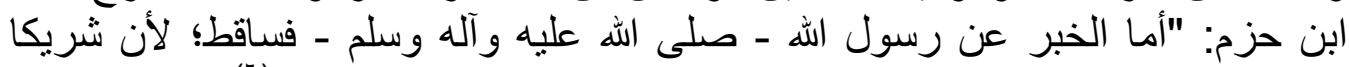

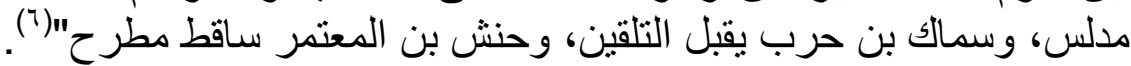

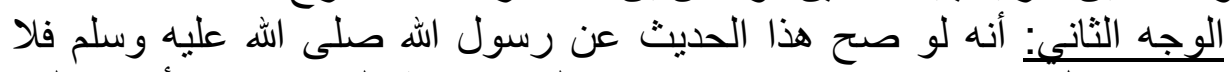

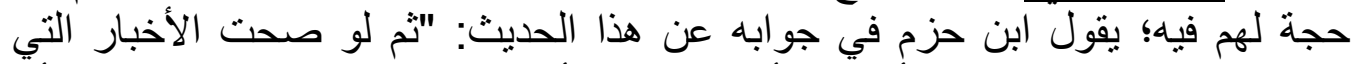

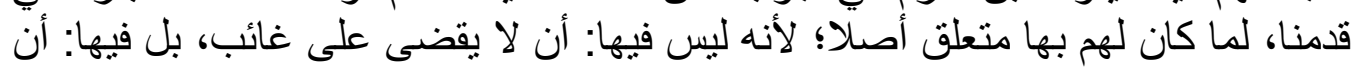

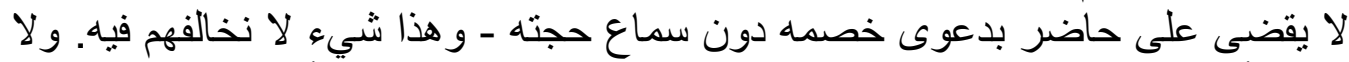

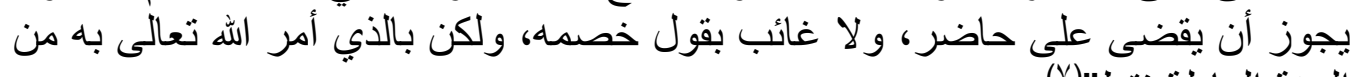

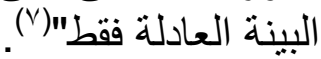

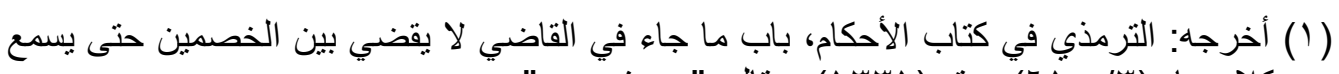

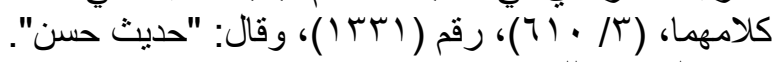

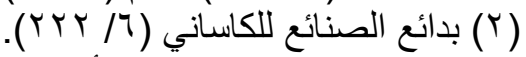

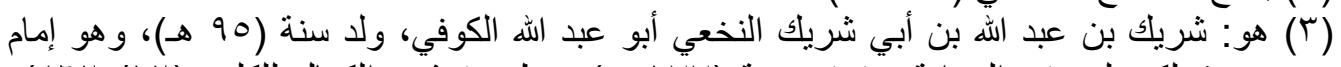

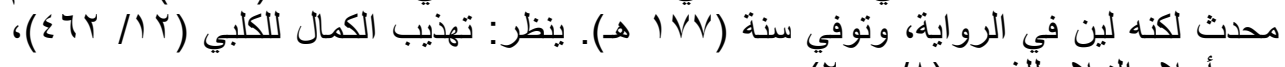

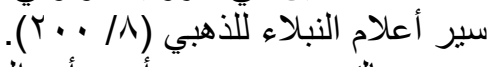

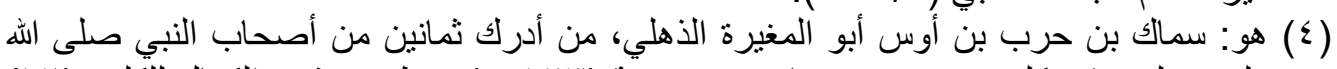

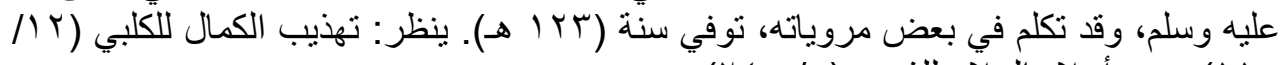

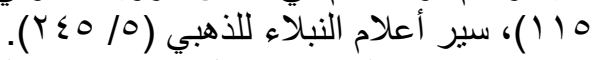

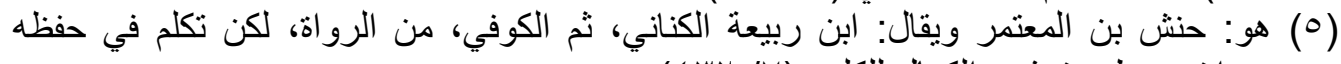

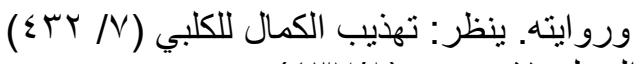

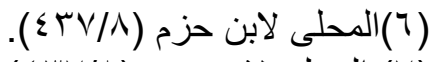

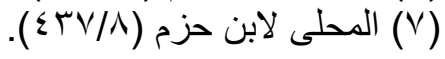




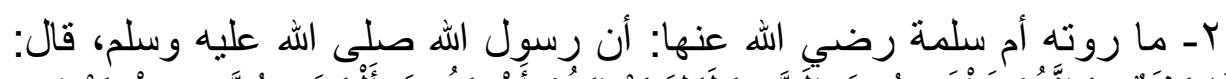

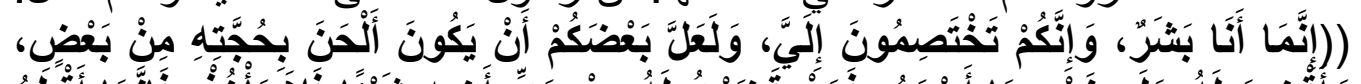

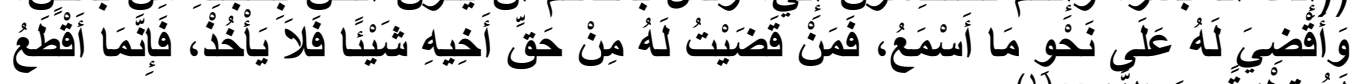

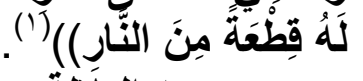

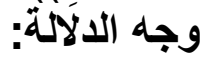

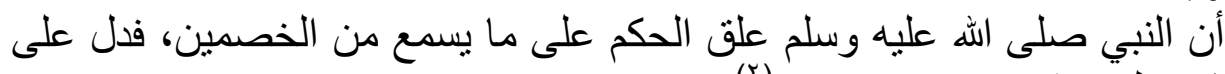

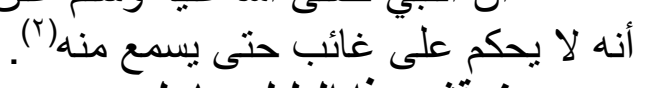
نوقش هذا الاليل بما يلي:

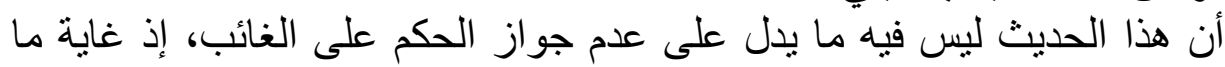

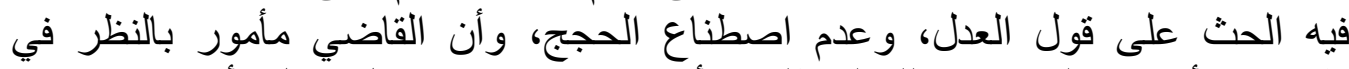

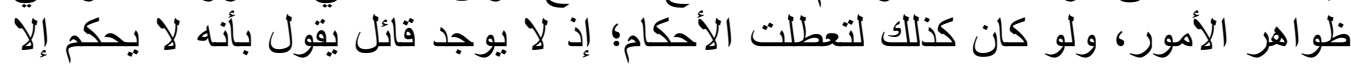

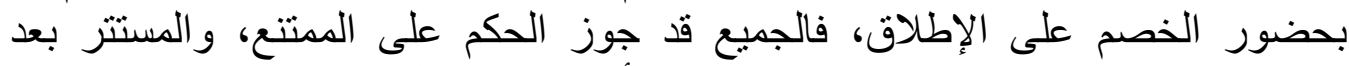

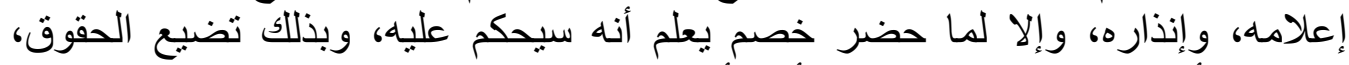

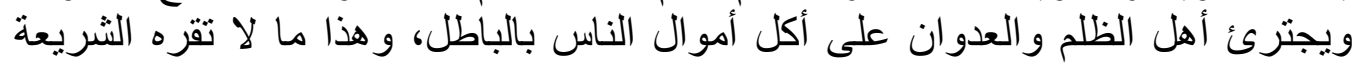

\section{الإسلامية بحال.

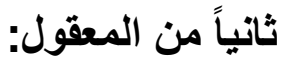

1 - أن القضاء هن الزعول: إلز بحق، وليس للقاضي ولاية على الغائب، فلا يصح الإلزام

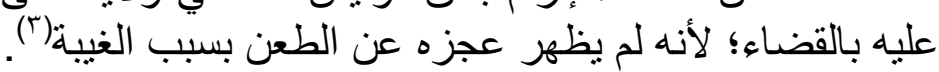

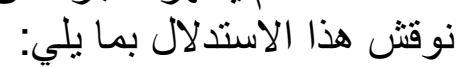

أن الإلزام بالحق لا يتوقة الإل على حضور الخصم، بل متى قامت البينة الموصلة

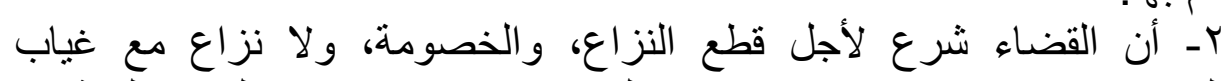
للحق، حُكم بها.

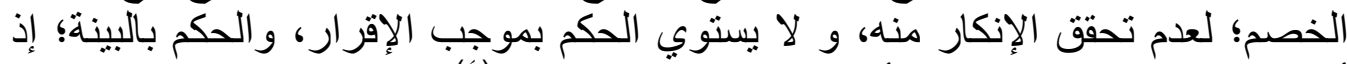

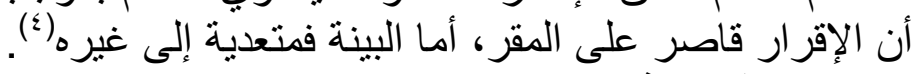

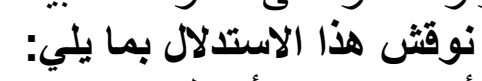

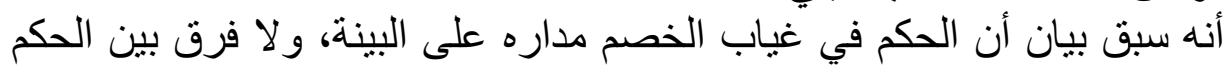

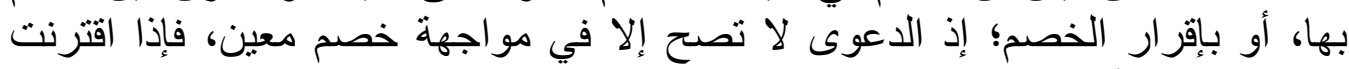

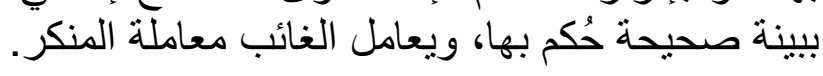

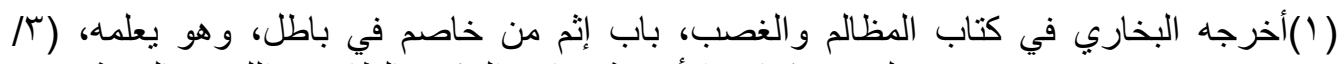

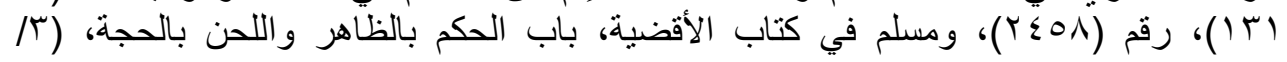

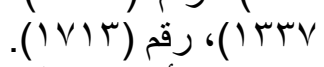

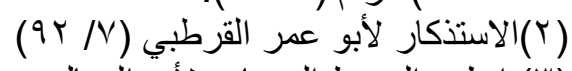

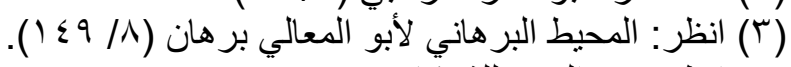


مجلة كلية الثريعة والقانون بتفهنا الأشراف ـ دقهلية العدد الثالث و العشرون لسنة إب ـ بم الجزء الرابع

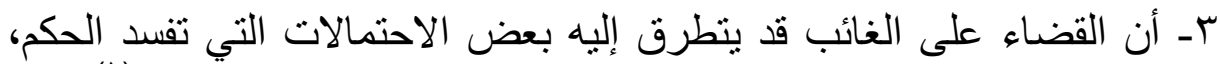

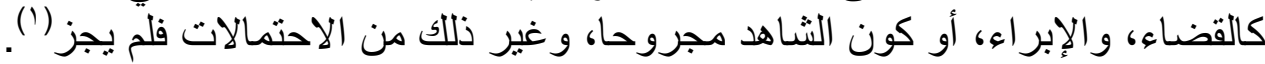

\section{نوقش هذا الاستدلال بما يالي:}

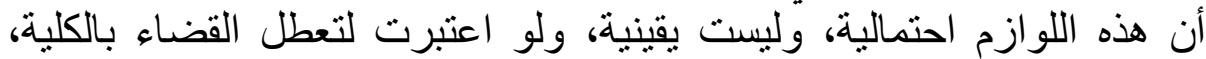

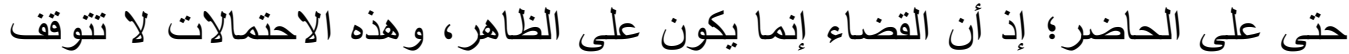

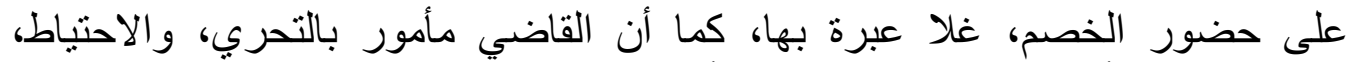
و الاستيثاق، ويتأكد ذلك في غياب الخصم أكثر منه في حضورها

\section{الهمالب النانبي}

\section{القائلون بجواز المكم على الغائب}

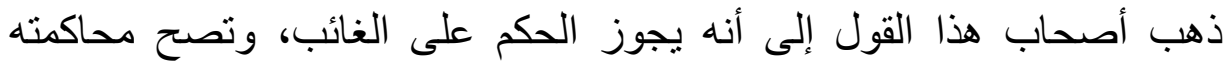

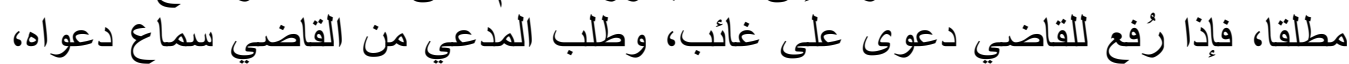

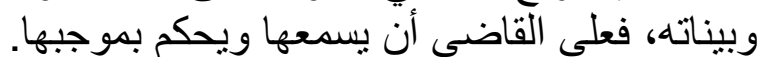

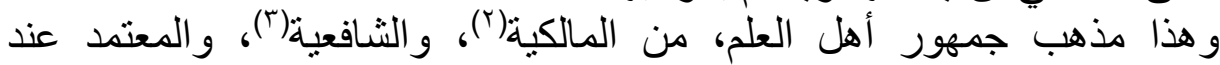

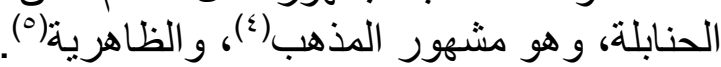

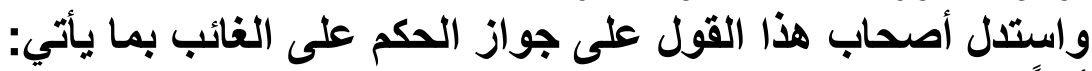

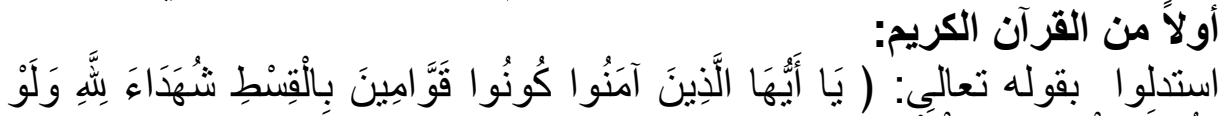

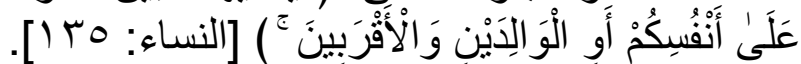

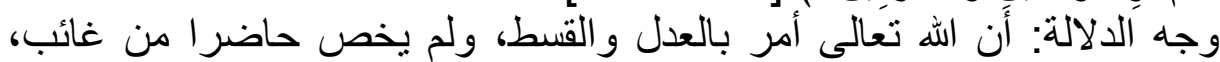
فصح وجوب الحكم على الغائب كما هو على الحسل الحاضر (؟).

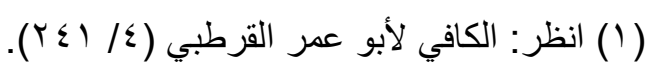

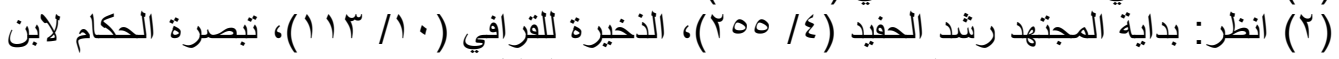

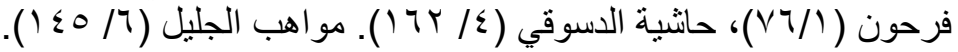

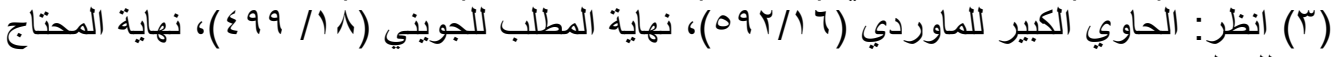

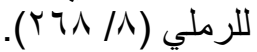

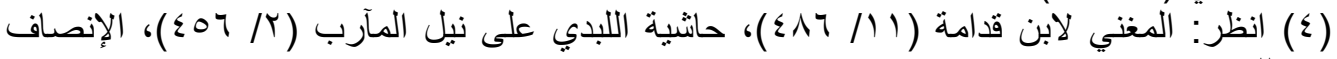

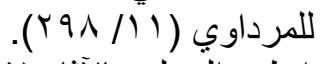

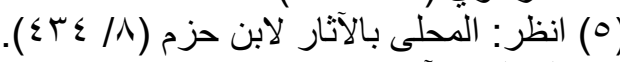

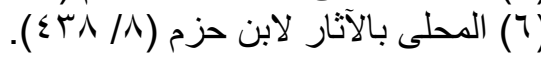




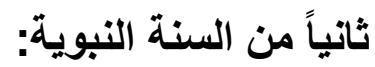

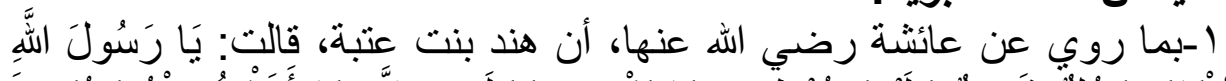

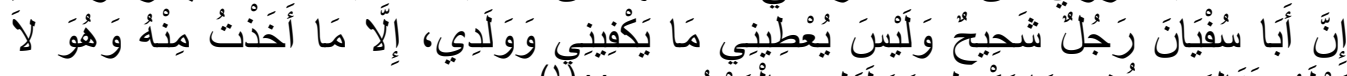

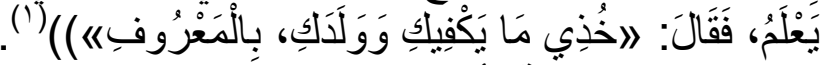

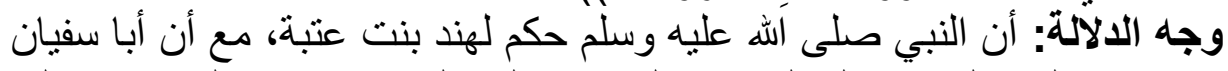

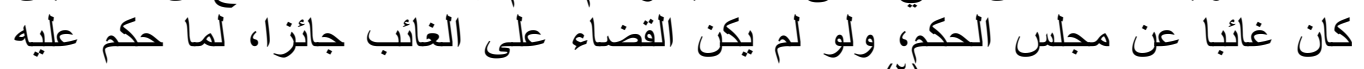

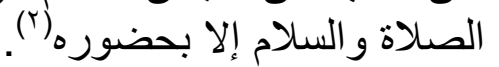

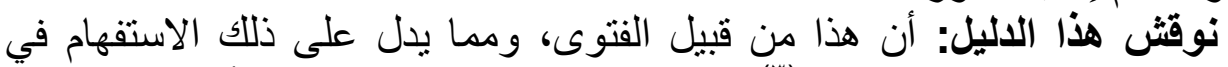

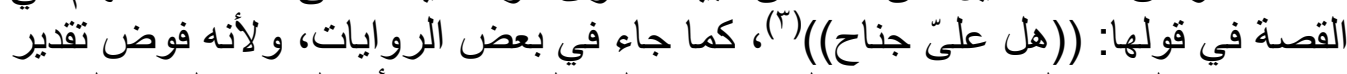

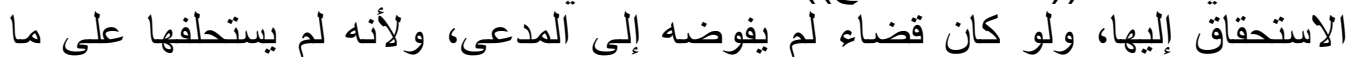

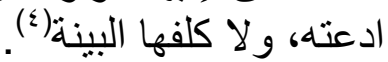

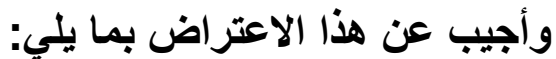

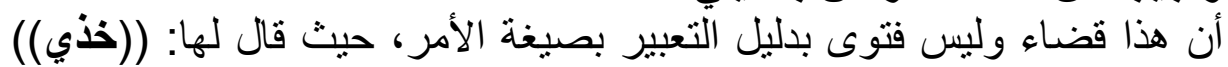

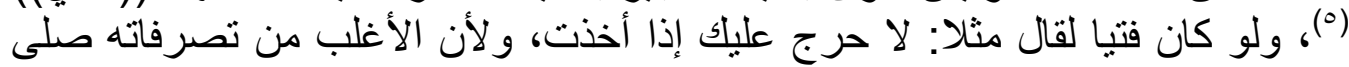

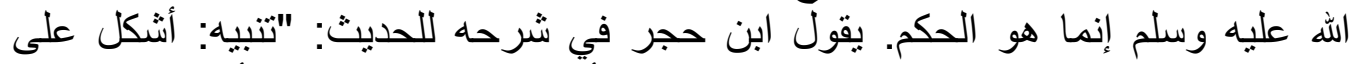

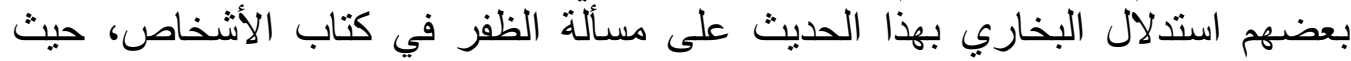

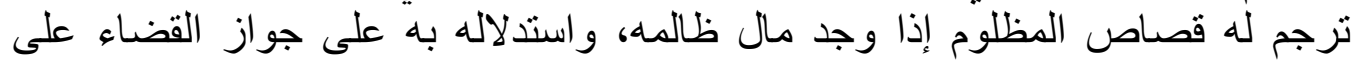

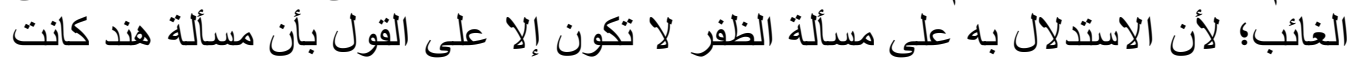

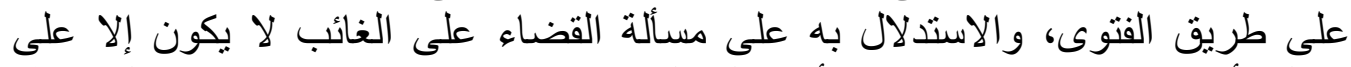

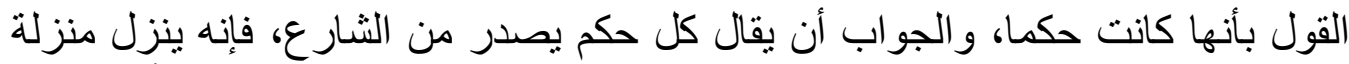

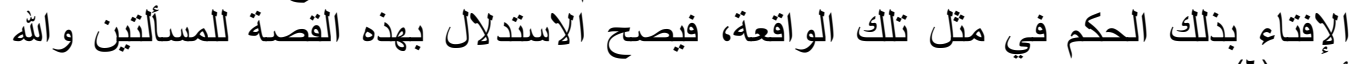

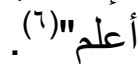

( (1) (أخرجه البخاري في كتاب النفقات، باب إذا لم ينفق الرجل فللمر أة أن تأخذ بغير علمه ما يكفيها

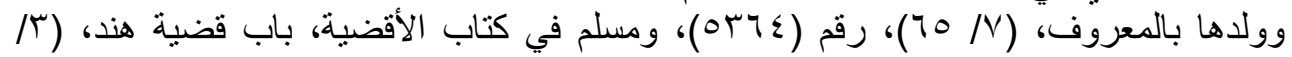

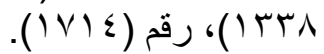

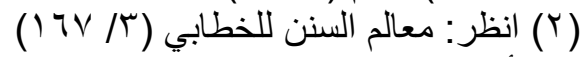

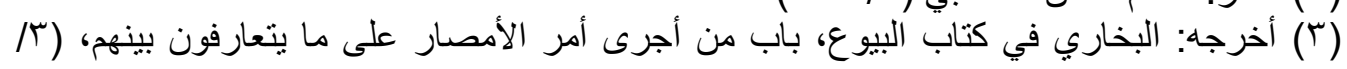

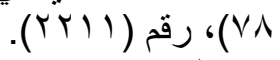

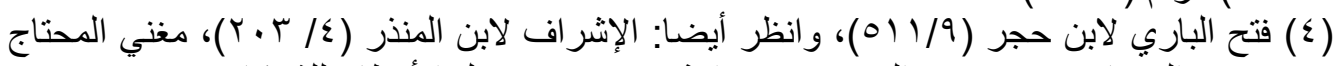

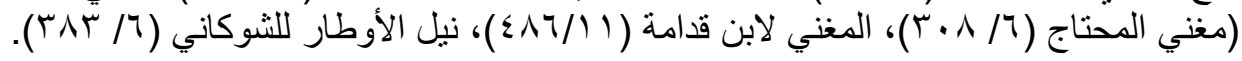

$$
\begin{aligned}
& \text { (0) سبق تخريجه ص10 } \\
& \text { (7) فتح الباري لابن حجر (9/ / (0) } 1 \text { (0). }
\end{aligned}
$$




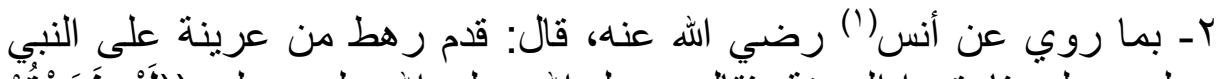

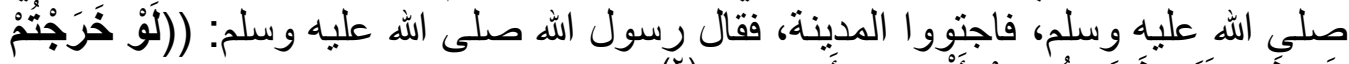

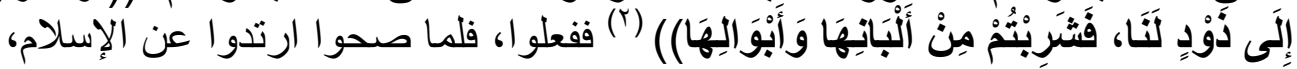

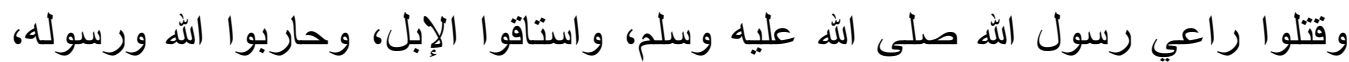

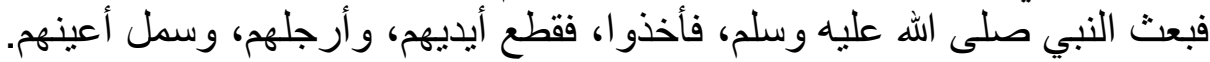

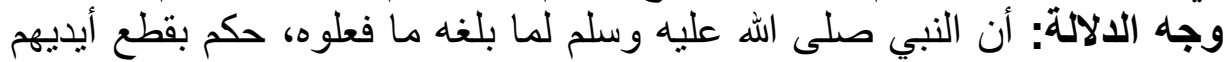

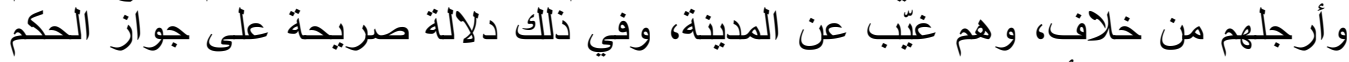

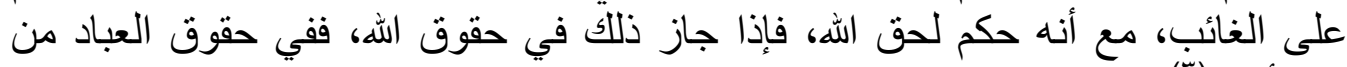

\section{نوقش هذا الاستلال بما يلي:}

أنه ورد في بعض هذا الروايتات بمالي: ـكما عند مسلم في صحيحه-: ((فبعث في أثرهم

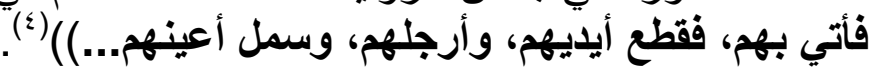

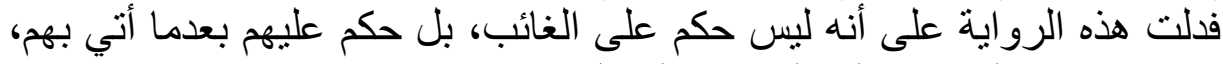

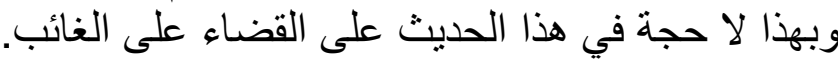

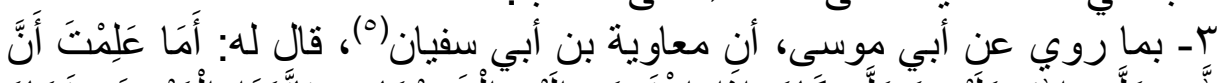

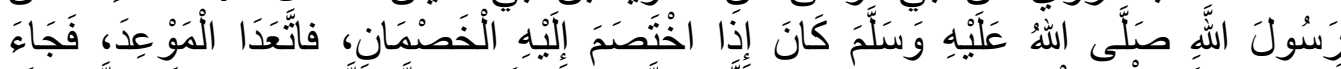

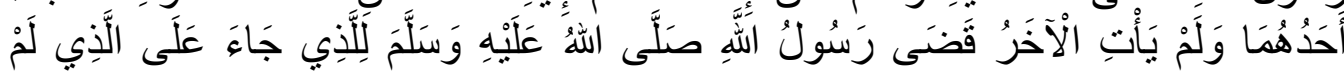

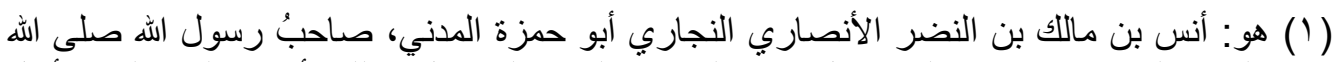

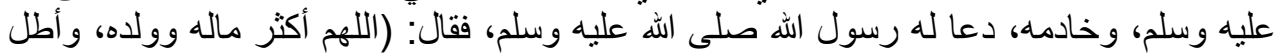

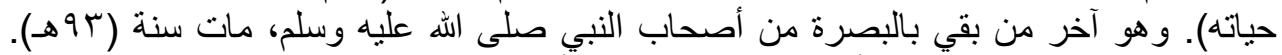

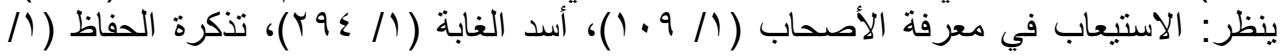

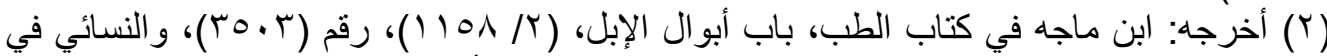

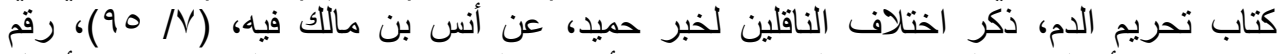

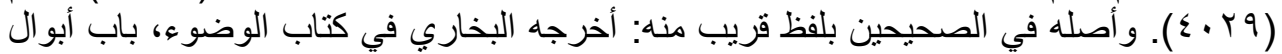

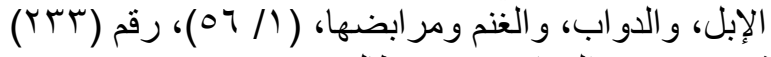

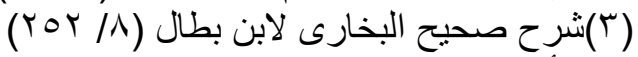

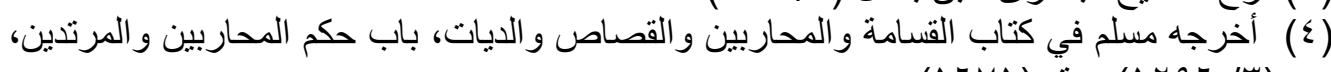

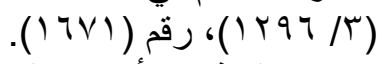

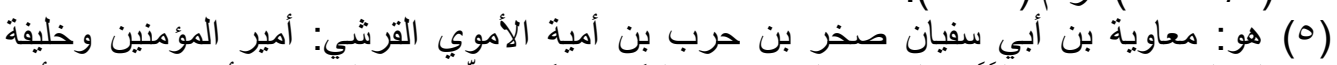

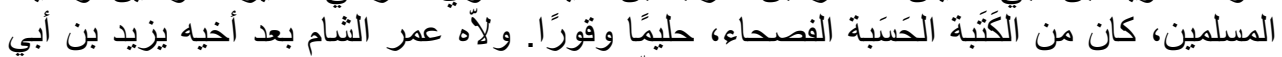

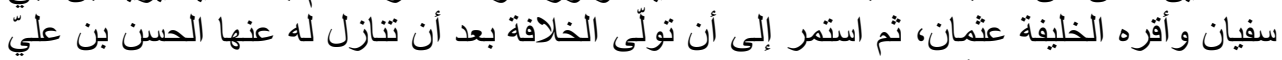

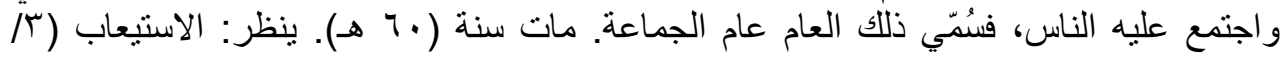

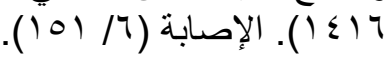




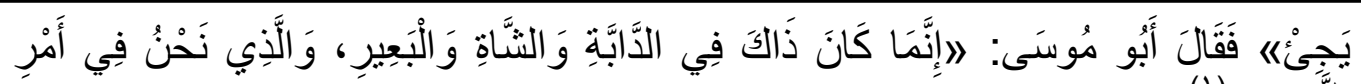

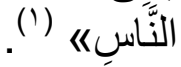

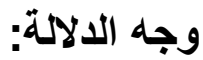

أن هذا الأثر صريح في الدة: الالة على الغائب، فل على جوازه.

\section{نوقش من وجهين:}

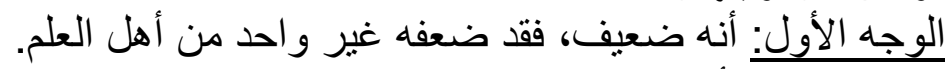

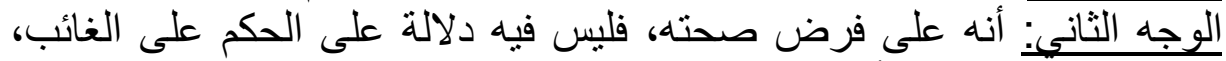

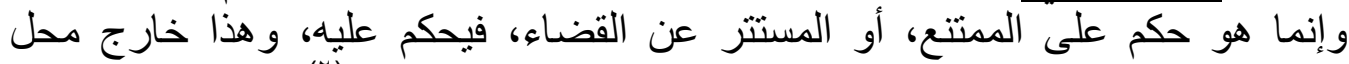

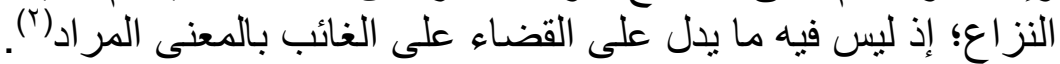

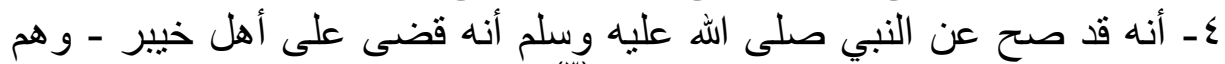

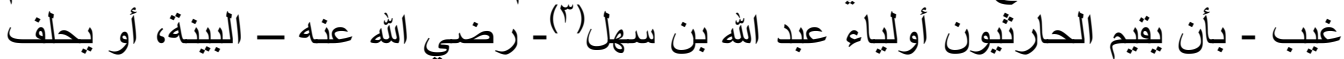

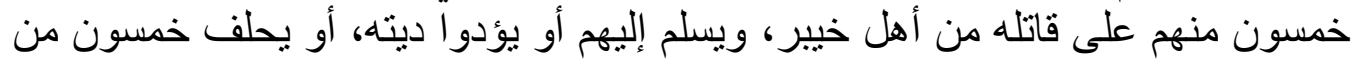

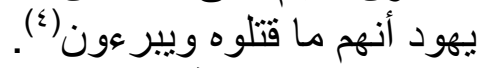
نوقش هذا الدليل:

أن هذه الواقعة وقعت في زمن لم تكن خيير فيه تحت حكم المسلمين، بدليل

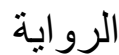

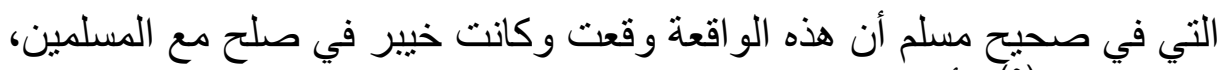

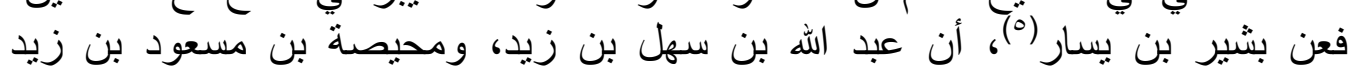

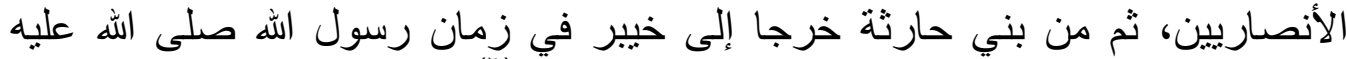

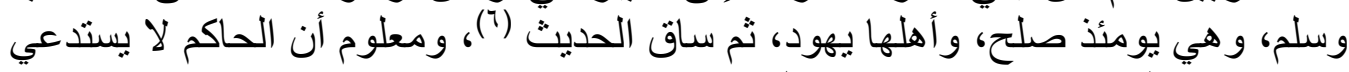
يستدعي من ليس في ولايته، ولا يدخل في في حكمه و ولا سيطرنه.

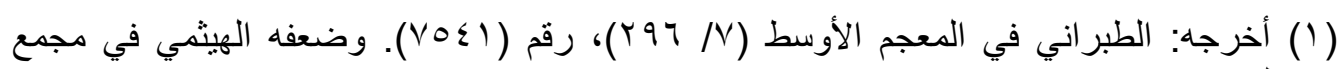

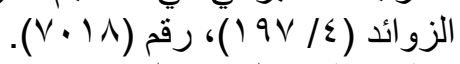

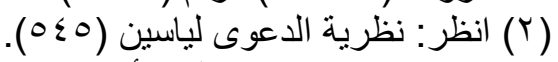

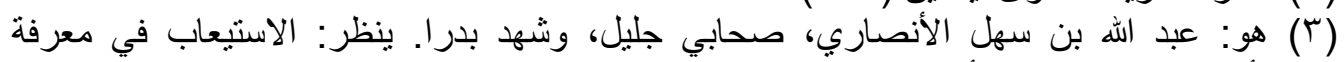

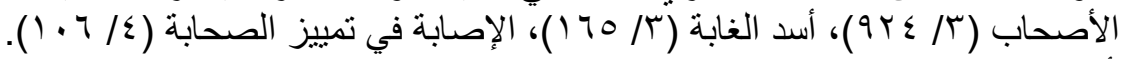

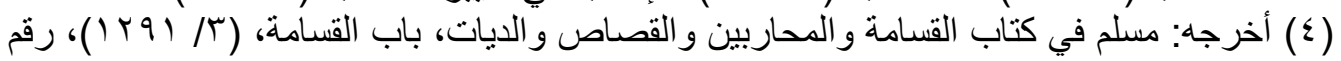
. (1779)

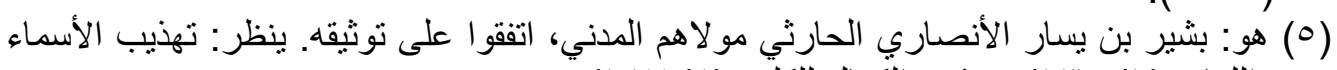

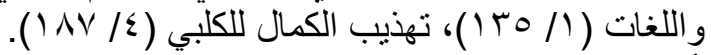

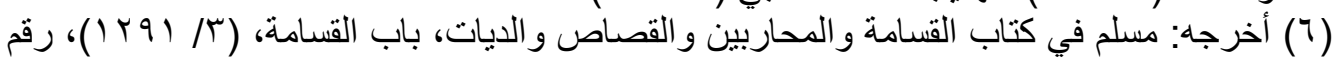




\section{وأجيب عن هذا الاستدلال:}

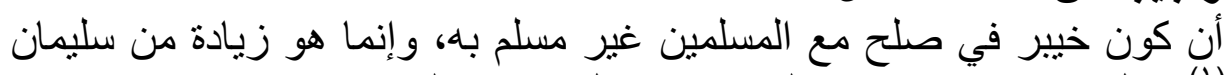

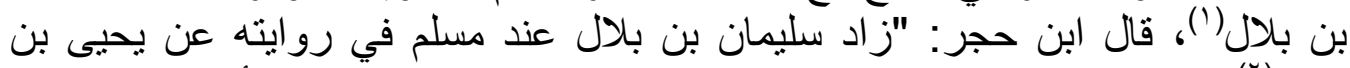

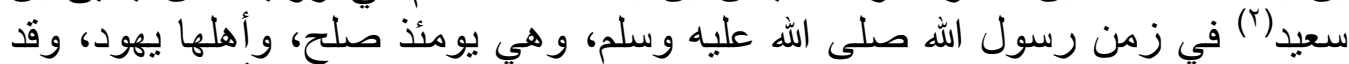

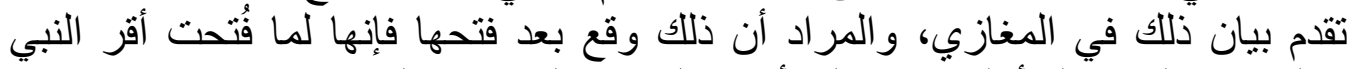

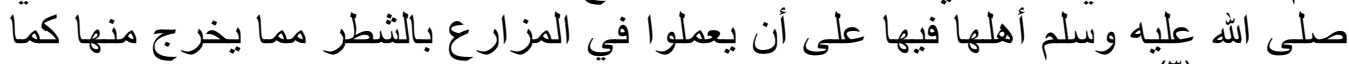
تقدم بيانه" (r)".

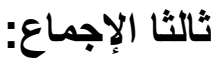

إجماع الصحابة، فقد روي عن عمر بن الخطاب " رضي الله عنه" أنه قال:

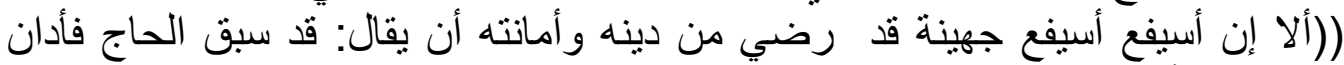

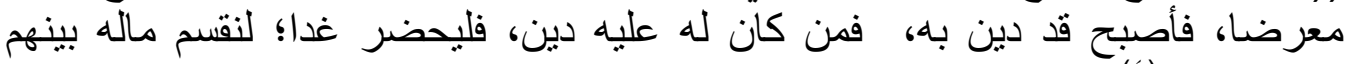

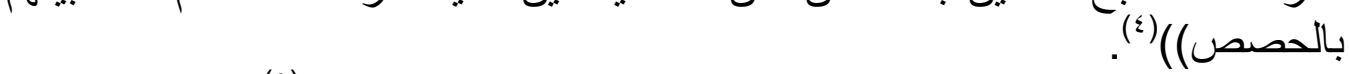

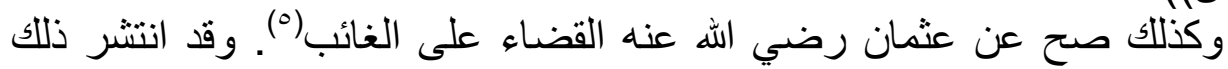
في الصحابة، ولم يعلم لله مخالف، قال الماوردي: "وليس لهان له مع انتشار قوله في الناس اله

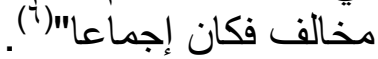
نوقش هذا الدليل بما يلإني: ليس في هذا الأثر ما يدلّ على أن الأسيفع كان غائبا، فلا يحتج به على القضاء

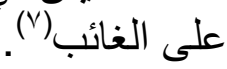

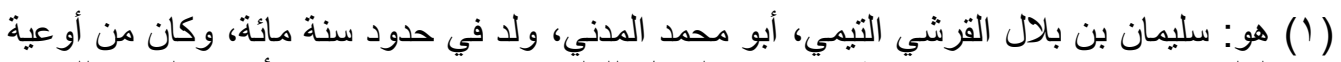

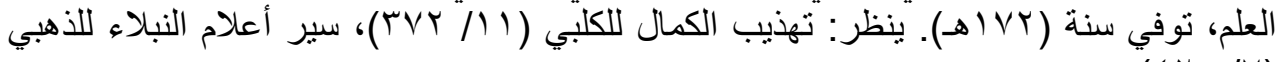

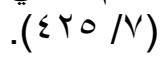

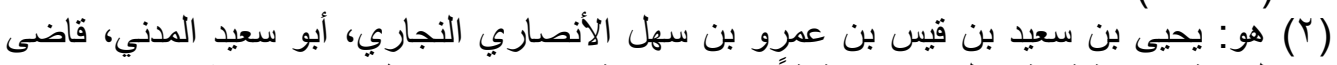

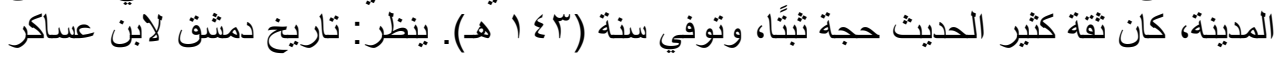

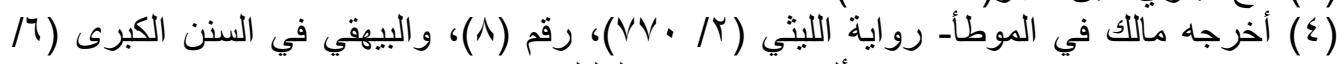

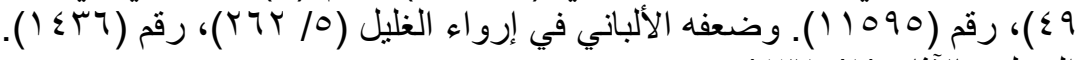




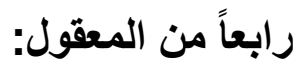

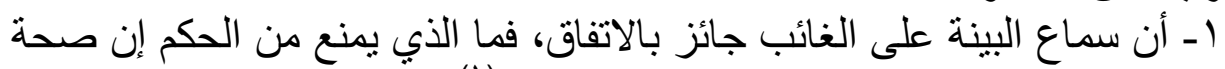

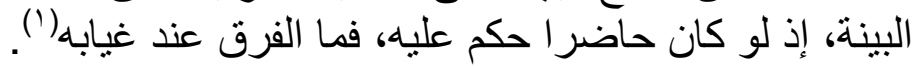

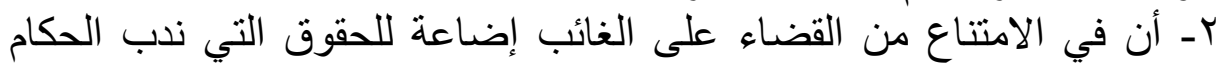

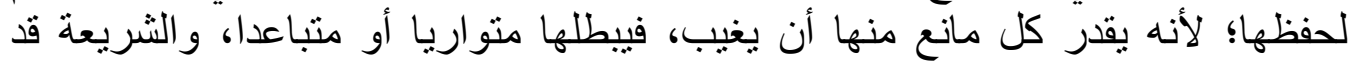

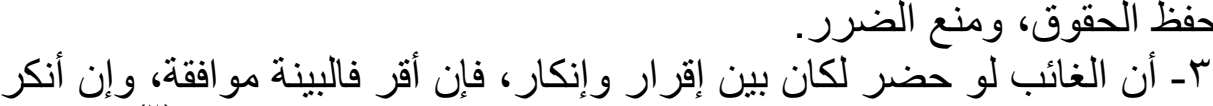
فالبينة حجة فلم يكن في الغيبة مانع من الحكم بالبينة في حالتي إقراره و إنكاره(؟).

\section{القول الراجح}

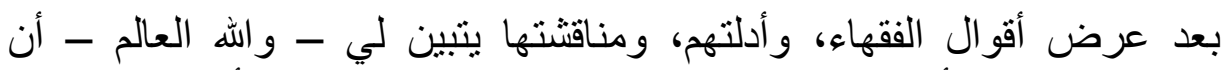

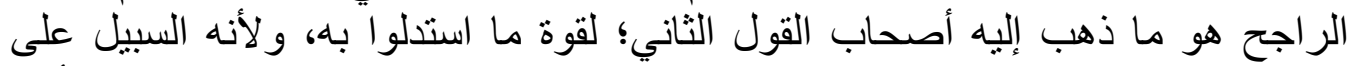

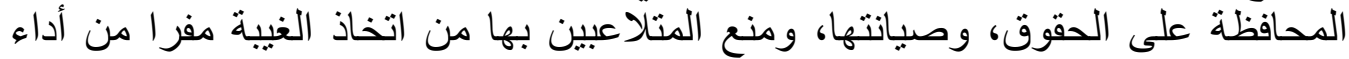

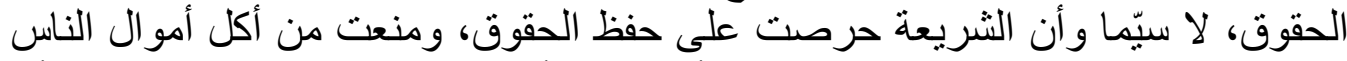

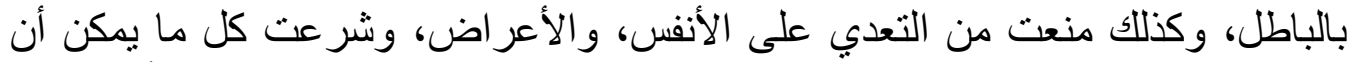

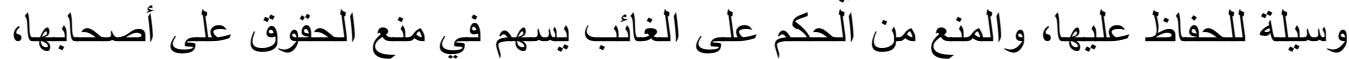

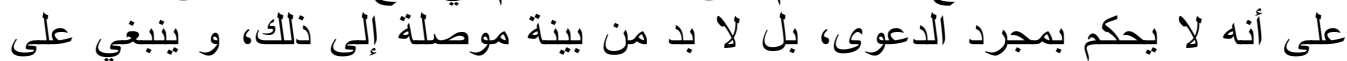

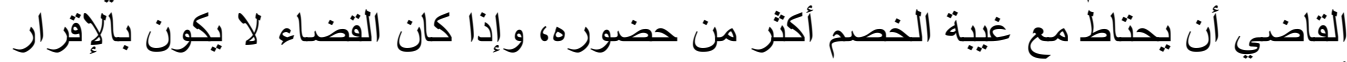
أو البينة العادلة، فإن حق الخصم مصان. 
مجلة كلية الثريعة والقانون بتفهنا الأثراف ـ دقهلية العدد الثالث والعثرون لسنة إr ـ بم الجزء الرابع

\section{خاتمة}

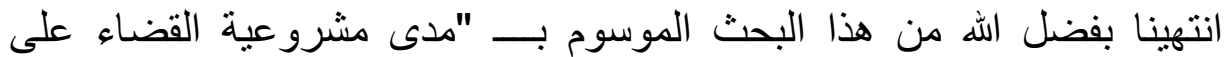

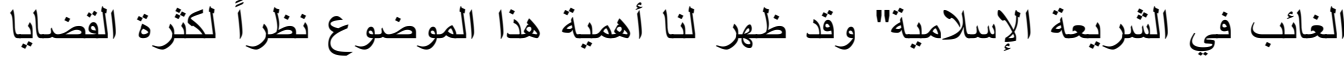

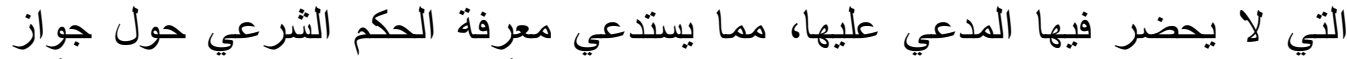

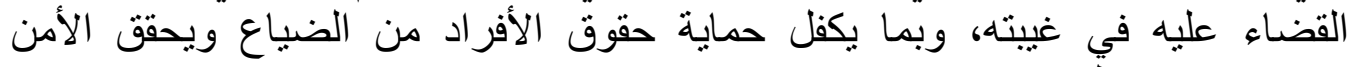
و الاستقرار في المجتمع.

هذا وقد توصلنا في نهاية هذا البحث إلى بعض النتائج والتوصيات وذلك على نحو ما يأتي:

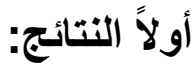

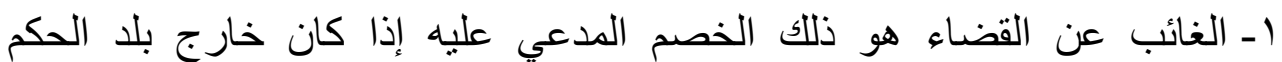

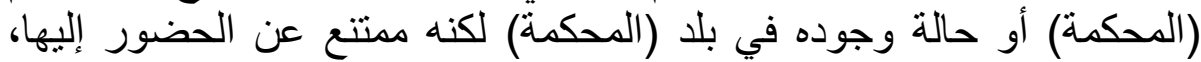

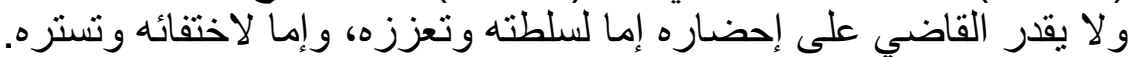

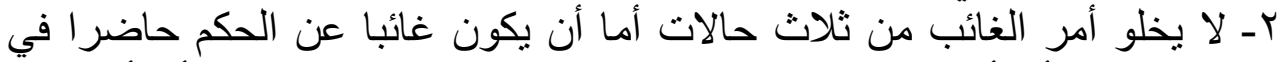

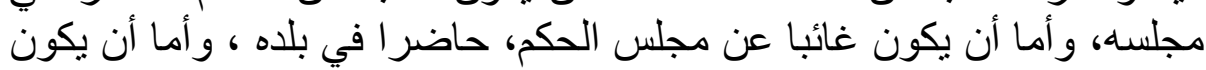
ب- سبب الخلاف الرئيسي في المسألة أن الأدلة الواردة في هذه المسألة، والتي التي

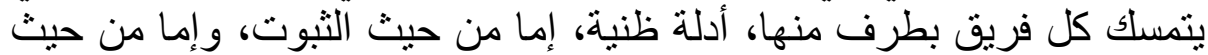

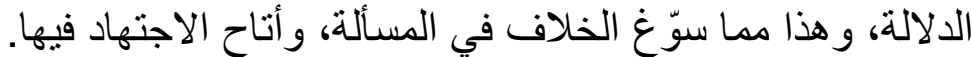

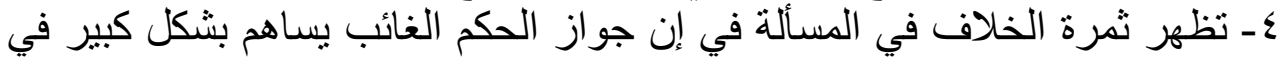

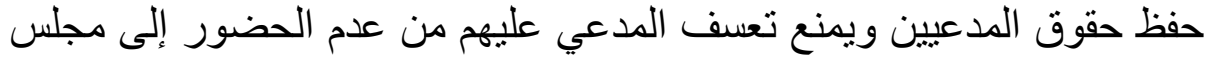
القضاء. 0- ترجح لنا جواز الحكم على الغائب سواء كان غائباً عن بلد الحكم أو كان حاضراً

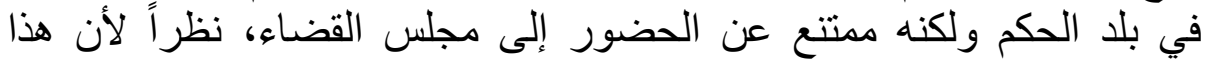
القول يكفل حماية الحقوق من الضياع. 


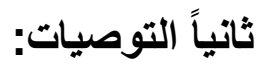

ا- نوصي القضاة بوجوب التأكد من غيبة المدعي عليه أو امتتاعه عن الحضور

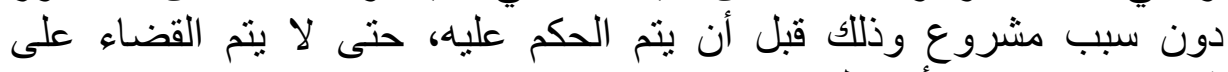

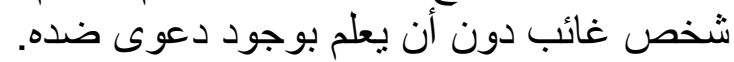

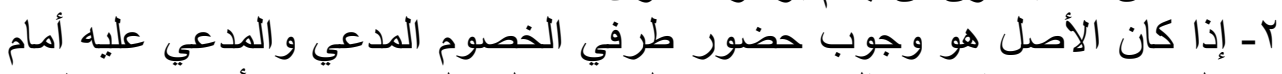

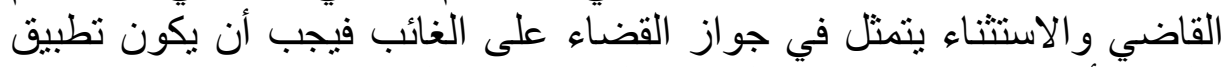

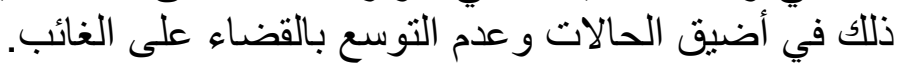

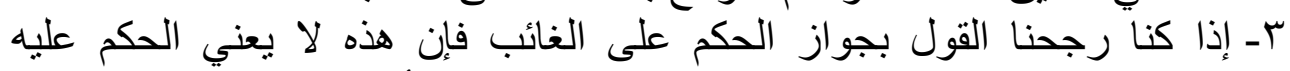

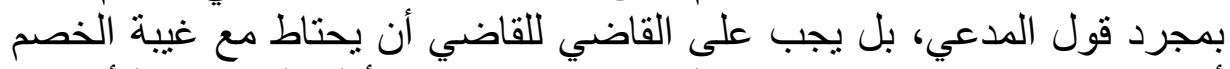

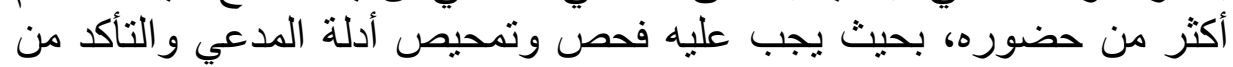
صحتها قبل الحكم على الغائب.

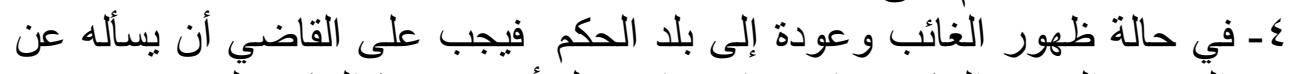

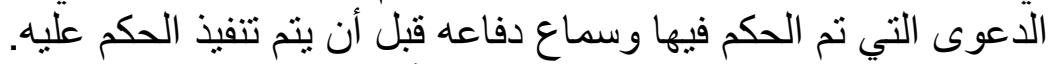

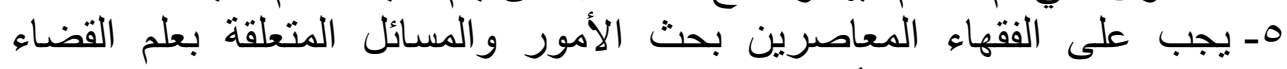

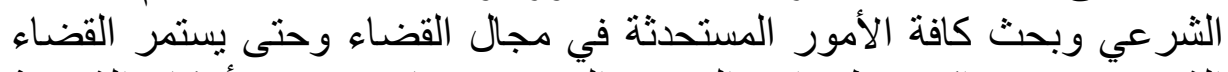
الثرعي في مواكبه تطورات العصر الحديث وبما يتفق مع أحكام الثريعة

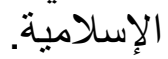




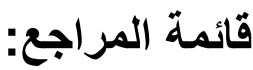

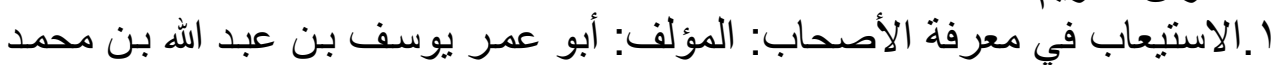

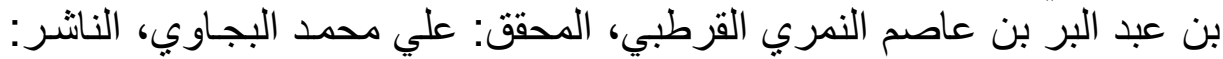

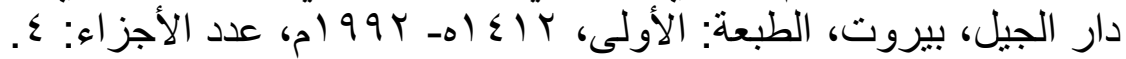

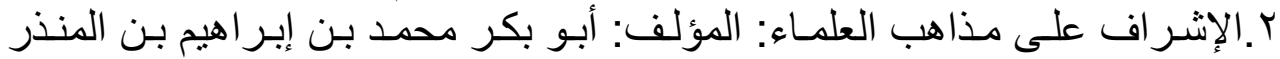

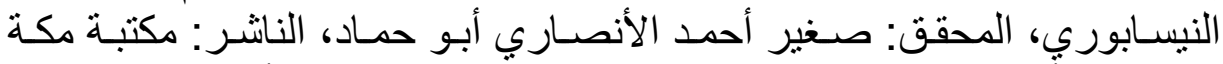

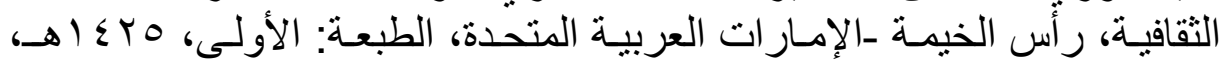

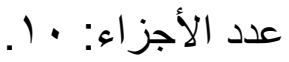

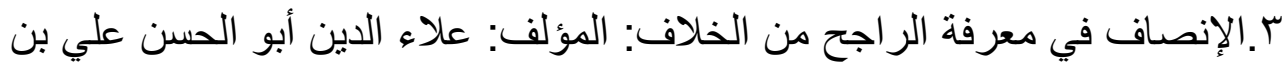

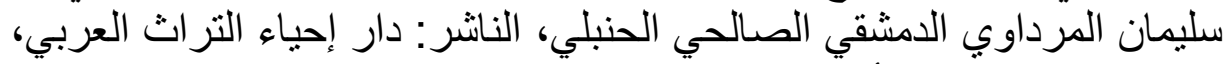

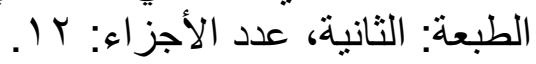
ع الاستذكار: المؤلف: أبو عمر يوسف بن بن عبد الله بن محمد بن عبد عبد البر بن بن عاصم

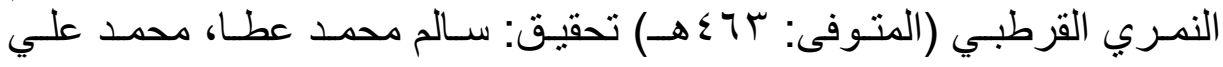
معوض

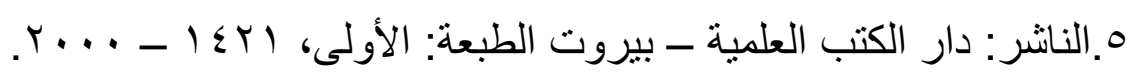

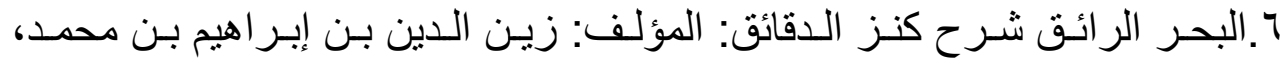

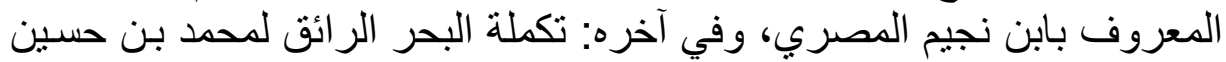

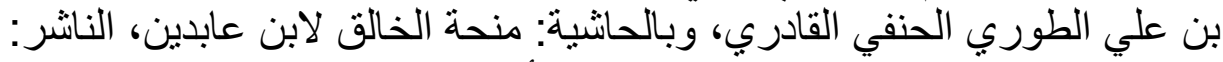

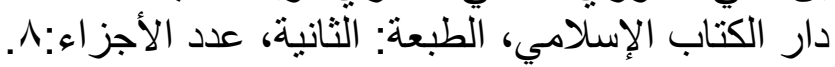

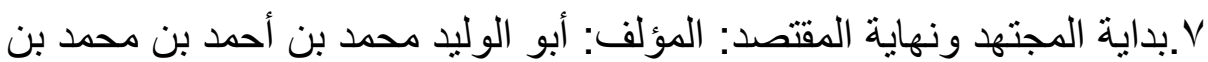

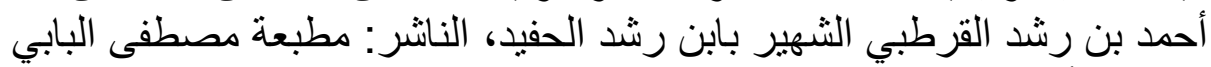

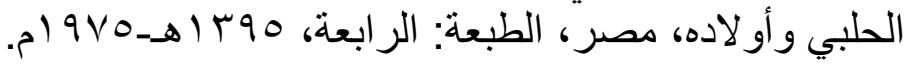

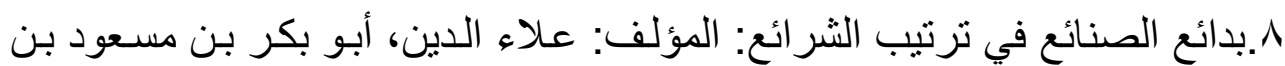

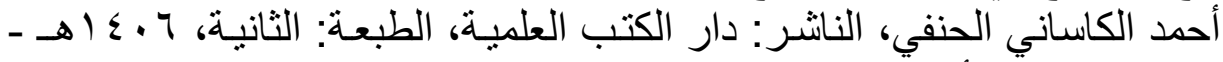

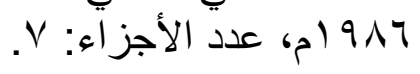

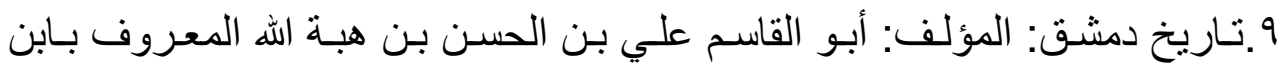

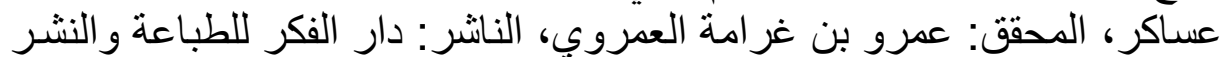

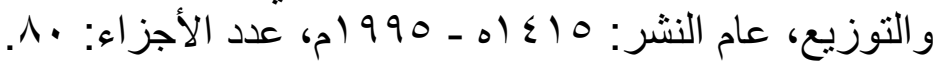




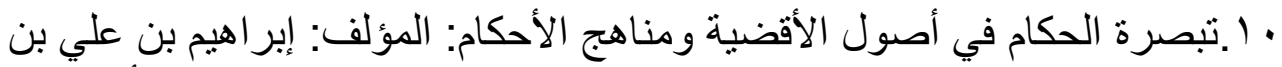

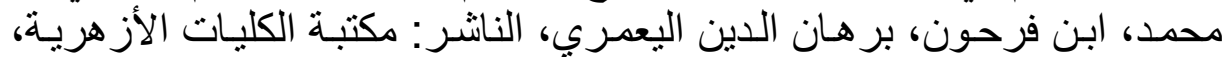

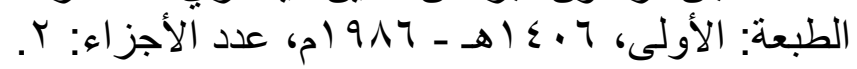

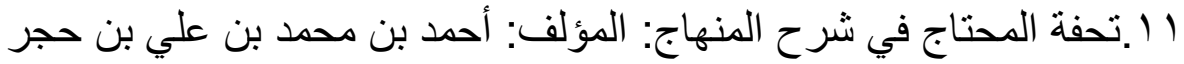

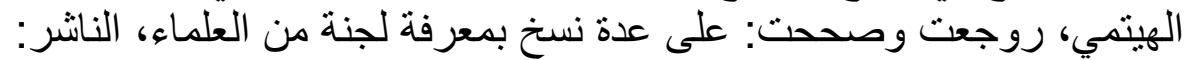

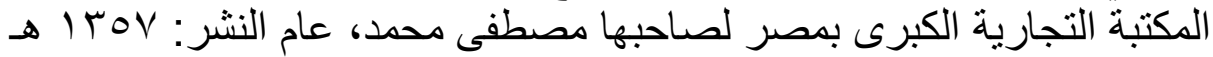
-

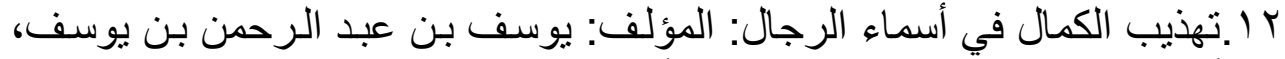

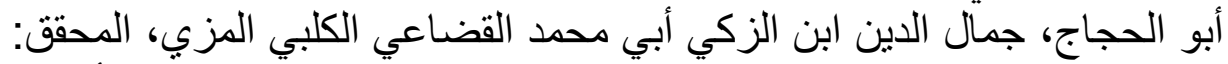

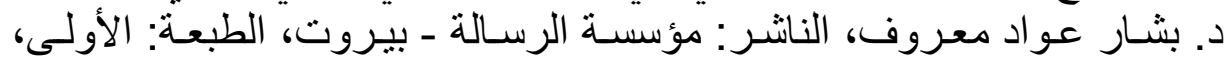

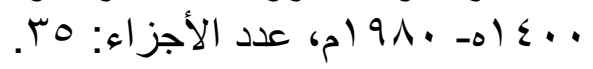

rا.حاثية الدسوقي على الشرح الكبير: المؤلف: محمد بن أحمد بن عرفة الدسوقي

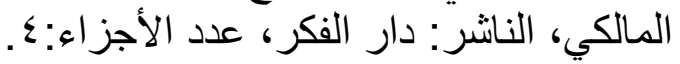

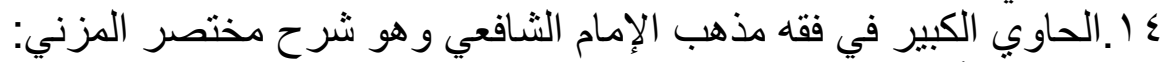

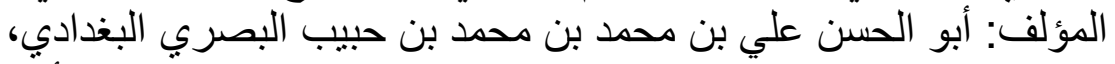

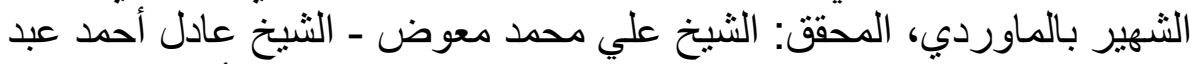

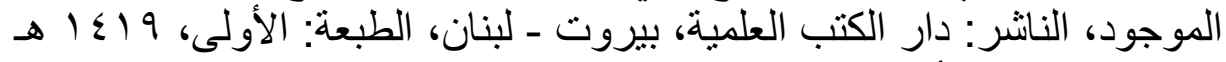

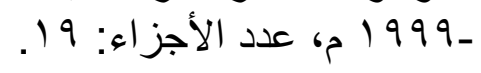

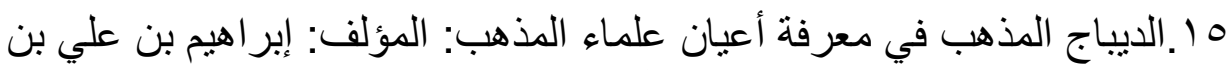

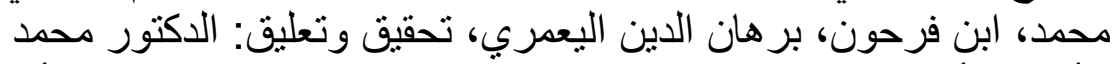

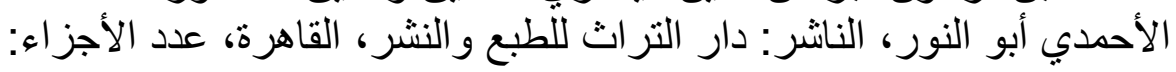

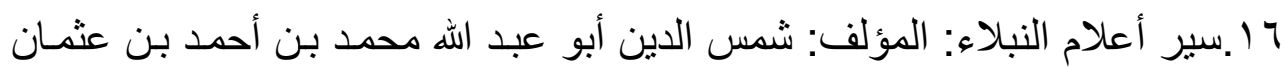

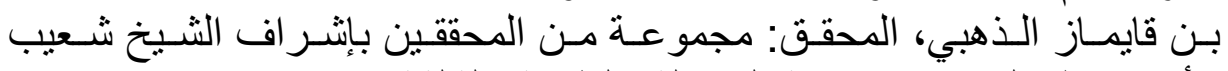

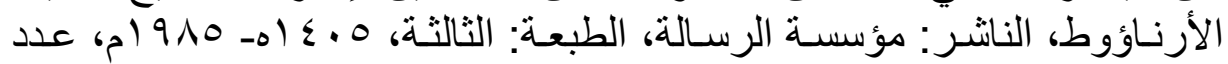

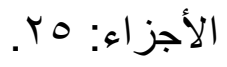

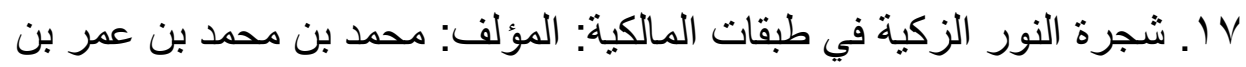

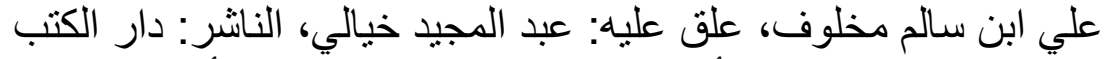

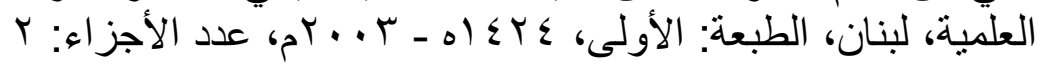

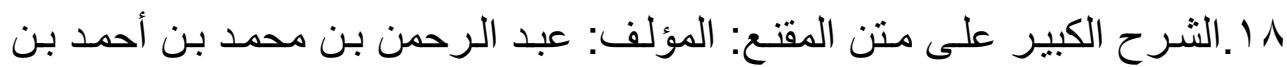

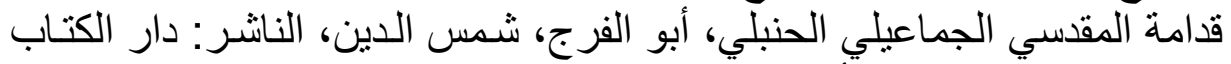

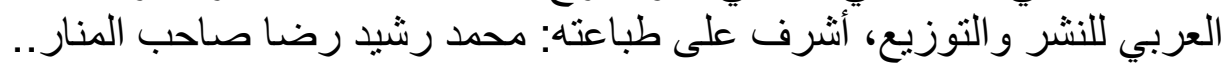


9 (.فتح الباري شرح صحيح البخاري: المؤلف: أحمد بن علي بن حجر العسقلاني،

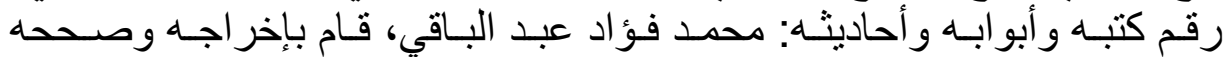

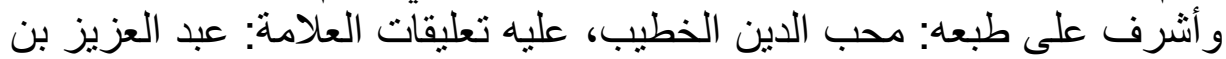

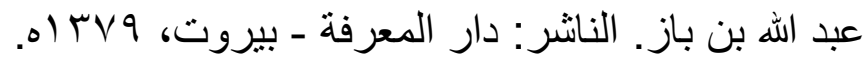

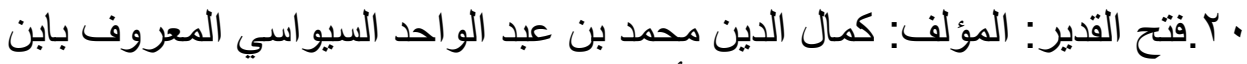

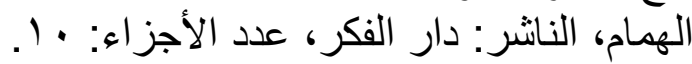

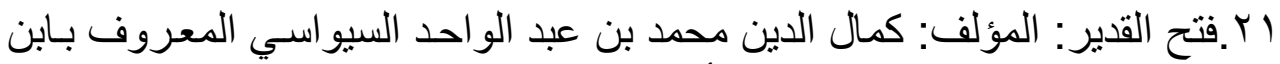

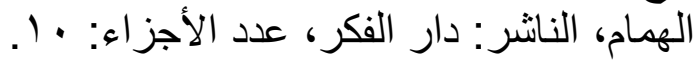

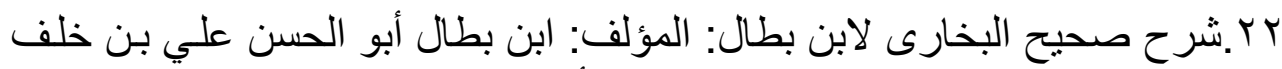

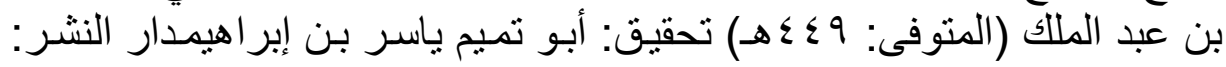

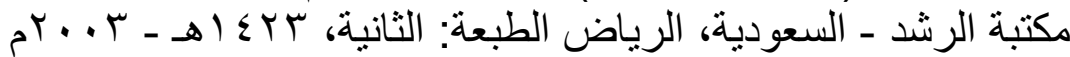

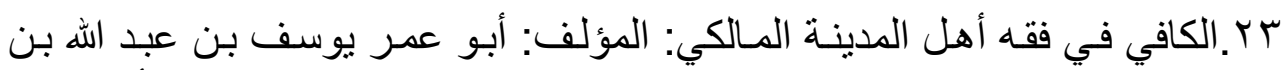

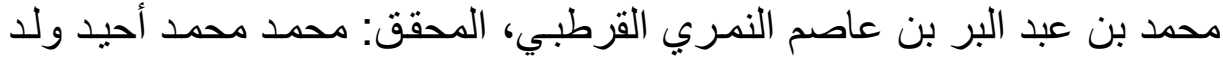

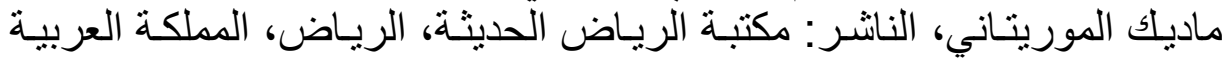

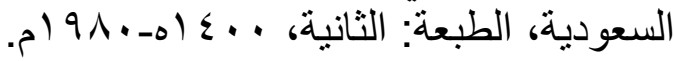

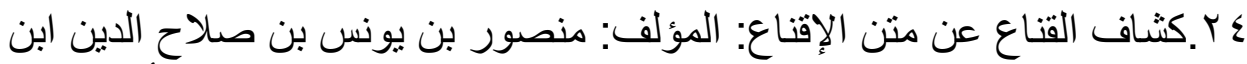

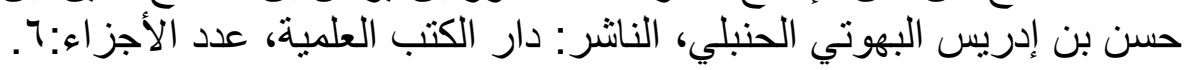

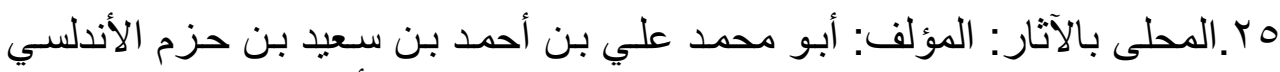

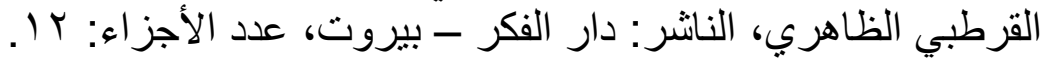

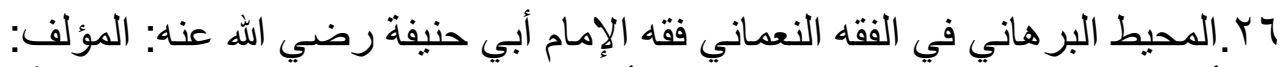

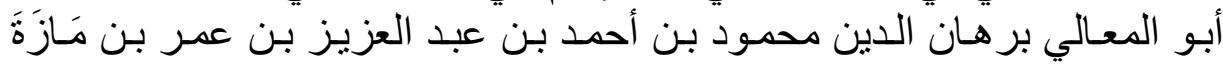

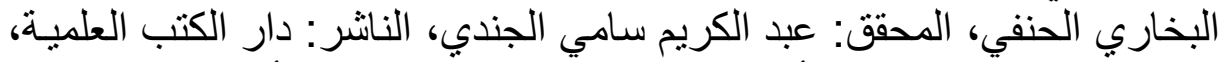

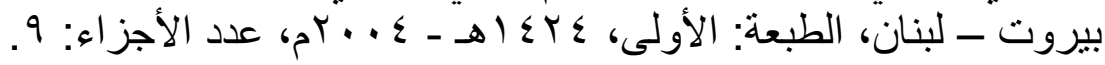

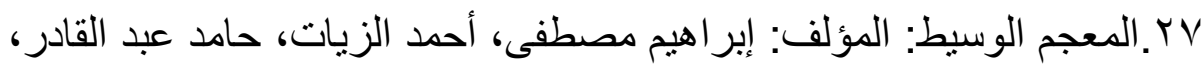

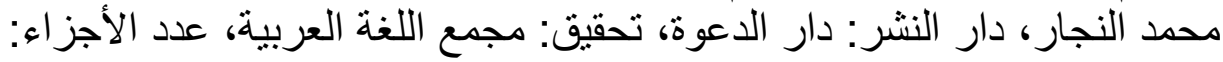
r ^ץ.المغني: المؤلف: أبو محمد موفق الدين عبد الله بن أحمد بن محمد، الثهير بابن

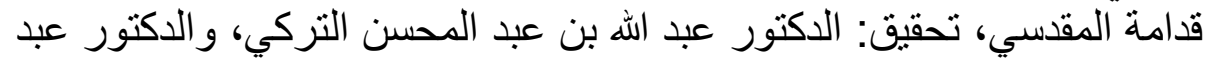

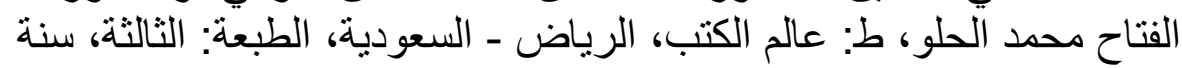
النشر: VI الهـ - 1997 (م. 
9. منتهى الإرادات: المؤلف: تقي الدين محمد بن أحمد الفتوحي الحنبلي الشهير

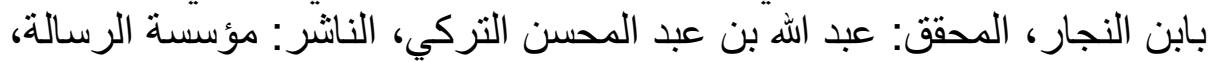

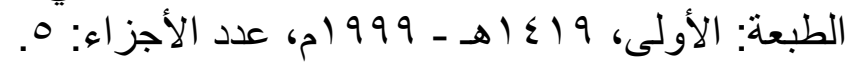

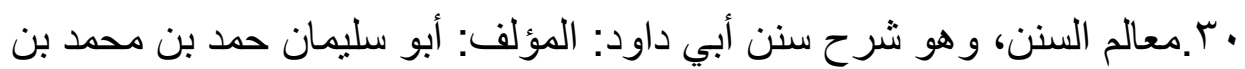

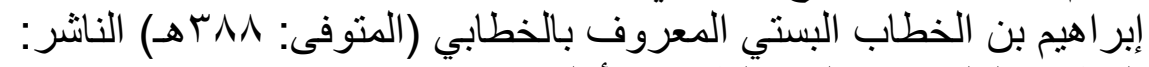

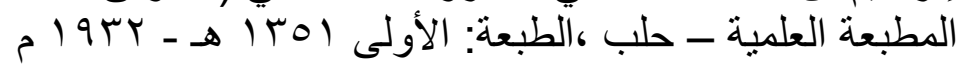

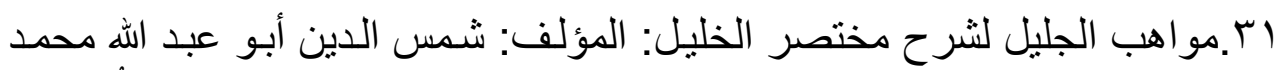

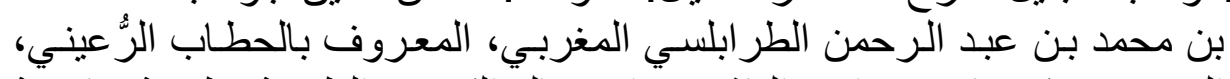

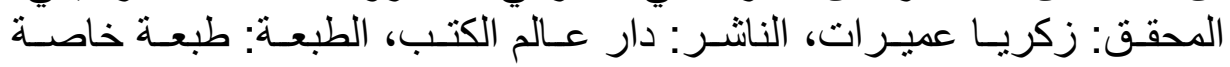

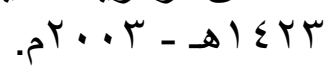

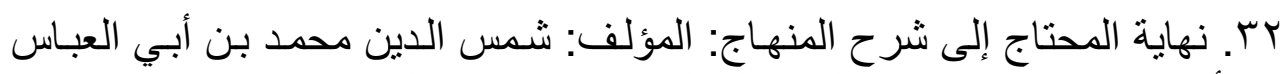

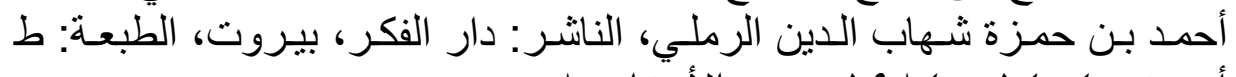

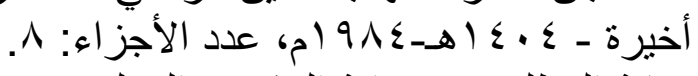

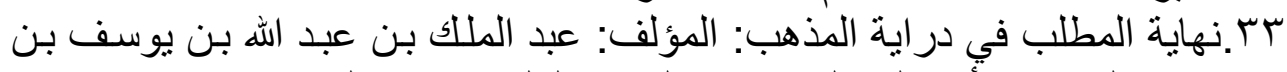

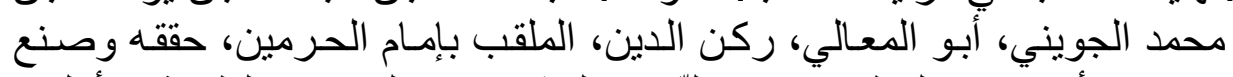

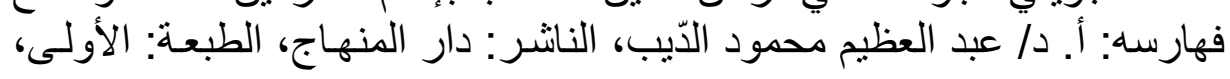

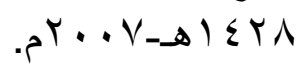

ع r.نيل الأوطار من أحاديث سيد الأخيار شـرح منتقى الأخبار : المؤلف: محمد بن الأنز

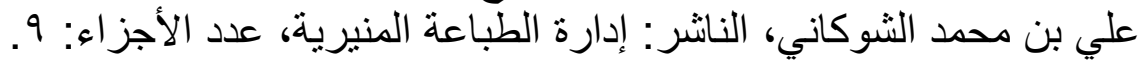

